OPEN ACCESS

Edited by:

Jorge G. Farias,

University of La Frontera, Chile

Reviewed by:

Yilei Wang,

Jimei University, China

Brad Buckley,

Portland State University,

United States

*Correspondence:

Kang Hee Kho

kkh@chonnam.ac.kr

Specialty section: This article was submitted to

Aquatic Physiology,

a section of the journal

Frontiers in Marine Science

Received: 12 January 2021

Accepted: 25 March 2021

Published: 13 April 2021

Citation

Hossen S, Sukhan ZP, Cho Y and Kho KH (2021) Effects

of Cryopreservation on Gene Expression and Post Thaw Sperm Quality of Pacific Abalone, Haliotis

discus hannai.

Front. Mar. Sci. 8:652390 doi: 10.3389/fmars.2021.652390

\section{Effects of Cryopreservation on Gene Expression and Post Thaw Sperm Quality of Pacific Abalone, Haliotis discus hannai}

\author{
Shaharior Hossen, Zahid Parvez Sukhan, Yusin Cho and Kang Hee Kho* \\ Department of Fisheries Science, College of Fisheries and Ocean Sciences, Chonnam National University, Yeosu, \\ South Korea
}

Pacific abalone, Haliotis discus hannai, is a high commercial seafood in South-East Asia. The aim of the present study was to determine effects of cryopreservation on gene expression and post thaw sperm quality of Pacific abalone. Two ions, $\mathrm{Na}^{+}(459.1 \pm 3.1 \mathrm{mM})$ and $\mathrm{Cl}^{-}(515.9 \pm 1.1 \mathrm{mM})$, were predominant in the seminal plasma $\left(\mathrm{pH}\right.$ : $6.8 \pm 0.1$; osmolarity: 1,126 $\left.\pm 3 \mathrm{mOsmL}^{-1}\right)$. Cryopreservation reduced mRNA expression levels of protein kinase $A$ (PKA-C) and heat shock proteins (HSP70 and HSP90) genes in sperm. Fluorescent technique was used to compare morphological defects, acrosome integrity (Al), plasma membrane integrity (PMI), mitochondrial membrane potential (MMP), and DNA integrity of sperm cryopreserved with five different cryopreservation solutions $\left(8 \% \mathrm{Me}_{2} \mathrm{SO}, 8 \% \mathrm{EG}, 6 \% \mathrm{PG}, 2 \% \mathrm{GLY}\right.$, and $2 \% \mathrm{MeOH}$ ). Droplet in tail and coiled tail defects was not observed for sperm cryopreserved with $8 \% \mathrm{Me}_{2} \mathrm{SO}$ or $2 \%$ GLY. Sperm cryopreserved with $8 \% \mathrm{Me}_{2} \mathrm{SO}$ showed improved DNA integrity and lower cryodamage than sperm cryopreserved with other cryoprotectants. Sperm to egg ratio of 10,000:1 was found to be the most suitable ratio for in vitro fertilization among different ratios tested. The fertilization rate of sperm cryopreserved with $8 \% \mathrm{Me}_{2} \mathrm{SO}$ was not significantly $(p>0.05)$ different from that of sperm cryopreserved with 2\% GLY. DNA fragmentation showed strongly negative relationships with sperm quality parameters. Sperm cryopreserved with $8 \%$ $\mathrm{Me}_{2} \mathrm{SO}$ showed higher post thaw quality and mRNA expression of sperm motility associated gene than those cryopreserved with other cryoprotectants. The present research suggests to use $8 \% \mathrm{Me}_{2} \mathrm{SO}$ for cryopreservation of Pacific abalone sperm as well as for hatchery production.

Keywords: sperm cryopreservation, mRNA expression, post thaw quality, morphological defects, DNA integrity, fertilization

\section{INTRODUCTION}

Pacific abalone, Haliotis discus hannai, is known as "soft gold" of the ocean due to its high commercial importance (Kong et al., 2020). It is a high-priced seafood item in South Korea, Taiwan, Japan, and China because it contains bioactive molecules with anticancer, antioxidant, anti-inflammatory, antimicrobial, and antithrombotic activities (Suleria et al., 2017; 
Sharker et al., 2020b). This economical valuable shellfish has been cultured in South Korea in the last three decades. Pacific abalone progeny via in vitro fertilization requires a large volume of sperm (Kim et al., 2020a). Genetically good quality progenitors are compulsory for producing improved offspring of Pacific abalone. Sperm cryopreservation serves as a vital tool to obtain good quality abalone progenitors (Liu et al., 2014). Commercial fertilization of this valuable species is depended on broodstock conditioning through effective accumulating temperature (EAT). For developing earlier gonadal maturation, a large number of matured abalone need to rear for around 3 months maintaining EAT. Sperm cryopreservation can solve the EAT maintenance problem of male abalone by supplying sperm in the breeding period.

Despite benefits of cryopreservation, it has also been reported that the freeze-thaw process can alter specific elements (ions, lipids, proteins, carbohydrates, etc.) of sperm (Peris-Frau et al., 2020). The freeze-thaw process of cryopreservation can modulate mRNA stability, protein and gene expression, and epigenetic content of sperm (Hezavehei et al., 2018). Cryopreservation significantly reduces mRNA expression levels of heat shock proteins (HSP70 and HSP90) in oyster sperm (Riesco et al., 2019) and bull sperm (Zhang et al., 2015a,b). Heat shock proteins (HSP70 and HSP90) are motility associated proteins of sperm (Zhang et al., 2015a,b). HSP70 could activate $\mathrm{Ca}^{2+}$ ATPase activity (Zhang et al., 2015a), whereas HSP90 is involved in intracellular calcium homeostasis and protein tyrosine phosphorylation of sperm ( $\mathrm{Li}$ et al., 2014). Calcium is a vital secondary messenger that plays a key role in controlling sperm motility (Lindemann and Kanous, 1989; Alshawa et al., 2019). Cryopreservation can also suppress protein kinase A (PKA) activity of post thaw sperm (Lee-Estevez et al., 2019). PKA regulates cation channels of sperm (also known as CatSper channels) (Orta et al., 2018) and phosphorylation of HSP90 (Li et al., 2020) in sperm. CatSper channels are crucial for motility and fertility of sperm (Mannowetz et al., 2017). Protein kinase A (PKA-C) is a sperm motility regulating gene in Pacific abalone (Kong et al., 2020) and other aquatic fish (Zilli et al., 2017) and shellfish (Nomura et al., 2005; Vacquier et al., 2014). The freeze-thaw process of cryopreservation can reduce the motility and viability of post thaw sperm. Sperm motility is essential to transport male DNAs to eggs for both external and internal fertilization (Sukhan et al., 2020). Recently, fluorescent technique has been applied to detect post thaw sperm quality including acrosome integrity (AI), plasma membrane integrity (PMI), and mitochondrial membrane potential (MMP) (Pereira et al., 2010; Liu et al., 2014; Kim et al., 2020b). Cryopreservation decreases the metabolic activity and post thaw sperm quality by altering mitochondrial membrane and structure (Madeddu et al., 2010; Figueroa et al., 2015). Cryopreservation leads to altered morphology of sperm by damaging the acrosome, mitochondria, and tail (Wooley and Richardson, 1978; O'connell et al., 2002). Cryodamage is a vital challenge for practical application of cryopreserved sperm in aquaculture and conservation programs (Xin et al., 2020). Cryodamage leads to impaired sperm structure and function by altering DNA integrity (Zilli et al., 2003). Sperm DNA integrity acts as an indicator of cryopreservation succession. It can be assessed with comet assay (Balamurugan et al., 2019). DNA fragmentation is responsible for reduced fertilization capacity and abnormal embryonic development (Gwo et al., 2003).

To date, sperm cryopreservation of Pacific abalone has been reported based on penetrating cryoprotectants (CPAs) (Kim et al., 2020a). Previous publication has focused on step-by-step fixation of cryopreservation conditions and recommended five CPAs with suitable concentration based on post thawed sperm motility. However, they only reported sperm viability results for sperm cryopreserved with $8 \% \mathrm{Me}_{2} \mathrm{SO}$ and 2\% GLY. To understand the effectiveness of cryopreservation, sperm viability assessment for all types of CPAs is essential. Effects of cryopreservation on gene expression, morphology, DNA integrity, and fertility of Pacific abalone have not been reported. For commercial hatchery production, quality assessment of cryopreserved sperm of Pacific abalone is essential. Hence, the aim of the present study was to assess effects of cryopreservation on gene expression and post thaw sperm quality of Pacific abalone. Expression levels of PKAC, HSP70, and HSP90 genes in post thaw sperm were determined using quantitative real-time PCR (qRT-PCR). Post thaw sperm quality was assessed by analyzing AI, PMI, MMP, morphology, sperm DNA integrity, and fertilization capacity.

\section{MATERIALS AND METHODS}

Experimental protocols were approved by the Animal Care and Use Committee of Chonnam National University (CNU IACUC-YS-2020-5). All experiments were conducted following Guidelines for the Care and Use of Laboratory Animals of the National Institutes of Health.

\section{Experimental Reagents}

Dimethyl sulfoxide $\left(\mathrm{Me}_{2} \mathrm{SO}\right)$, ethylene glycol (EG), propylene glycol (PG), glycerol (GLY), and methanol (MeOH) were obtained from Sigma-Aldrich Pty Ltd., United States. Phosphate buffer saline (PBS) was purchased from Life Technologies Ltd., Paisley, United Kingdom. LIVE/DEAD ${ }^{\circledR}$ sperm viability kit and LysoTracker ${ }^{\mathrm{TM}}$ Green DND-26 were supplied from Invitrogen Molecular Probes, Life Technologies ${ }^{\mathrm{TM}}$, United States. Rhodamine 123 (Rh123) and propidium iodide (PI) were obtained from Sigma-Aldrich Pty Ltd. Comet assay ${ }^{\circledR}$ kit was obtained from Trevigen Inc., Gaithersburg, MD, United States.

\section{Sperm Collection and Handling}

Pacific abalone were collected from a commercial abalone hatchery (Tou-Jong soosan, Yeosu, South Korea) during the spawning season. Three-year-old abalone with swollen and large gonads were carefully chosen based on their whitish milky (male) and greenish color (female). Good quality males were collected from the stock of abalone and kept in plastic cages. Abalone were acclimatized in a cemented tank with continuous supply of aeration and seawater $\left(16.5^{\circ} \mathrm{C}\right)$.

A total of 140 abalone (male and female) were used to conduct the experiment. Experimental abalone were kept in plastic cages (20 individuals in each cage). Cages were submerged into 
seawater $\left(20^{\circ} \mathrm{C}\right)$ for $1 \mathrm{~h}$ to pre-induce spawning of abalone. After that, they were dried with paper towels and kept in sunlight for 20 min with shell facing down. If sperm were not released within $20 \mathrm{~min}$, abalone were stripped gently to collect sperm. Samples were then transferred to Eppendorf tubes using plastic disposable transfer pipets and immediately kept on ice. Sperm pool was prepared based on collected sperm from at least five males.

\section{Quality Evaluation of Fresh Sperm}

Sperm quality indicators such as motility, AI, PMI, MMP, and DNA integrity were assessed to ensure the quality of fresh sperm. Motility was observed according to method described by Kim et al. (2020a). Briefly, sperm were diluted 10 times with filtered seawater (FSW) in an Eppendorf tube. Subsequently, $2 \mu \mathrm{L}$ of diluted sample was gently mixed with $100 \mu \mathrm{L}$ of FSW on a glass slide (Superfrost plus, microscope slide, Fisher Scientific, United States). Motility was calculated six times using six different samples $(n=6)$. AI, PMI, and MMP were detected using LYSO-G/PI ${ }^{\circledR}$, LIVE/DEAD ${ }^{\circledR}$, and Rh123/PI ${ }^{\circledR}$ (described in sections "Acrosome Integrity Test," "Plasma Membrane Integrity Test," and "Mitochondrial Membrane Potential Test") methods, respectively.

\section{Ion Composition of Seminal Plasma}

Sperm samples ( $N=20$ abalone, mid-May 2019) were centrifuged (Microfuge $^{\circledR}$ 20R centrifuge, Beckman Coulter, Inc., Brea, CA, United States) at $12,000 \mathrm{~g}$ for $20 \mathrm{~min}$ at $4^{\circ} \mathrm{C}$ to separate the seminal plasma. The $\mathrm{pH}$ of seminal plasma was immediately detected using comparator $\mathrm{pH}$ strips with an increment of $0.2 \mathrm{U}$ (Johnson ${ }^{\circledR}$ test papers, United Kingdom). Seminal plasma samples were stored at $-20^{\circ} \mathrm{C}$ until analysis of ion compositions. Anion contents (mM) of seminal plasma were assessed using ion chromatography (930 Compact IC Flex, Metrohm, Switzerland) fitted with a column (Metrosep A Supp 5) and a conductivity detector. Components were separated using $3.2 \mathrm{mM} \mathrm{Na} \mathrm{CO}_{3}$ and $1.0 \mathrm{mM} \mathrm{NaHCO} 3$ eluent with a flow rate of $0.7 \mathrm{~mL} \mathrm{~min}^{-1}$. Cation compositions $(\mathrm{mM})$ of seminal plasma were assessed using an inductively coupled plasma-optical emission spectrometer (Optima 7300 DV ICPOES, PerkinElmer, United States). A micro-osmometer (Fiske ${ }^{\circledR}$ Model 210 Micro-Osmometer, Norwood, MA, United States) was used to determine the osmolarity $\left(\mathrm{mOsm} \mathrm{L}^{-1}\right)$ of seminal plasma.

\section{Cryopreservation of Pacific Abalone Sperm}

Sperm cryopreservation was accomplished following the previously reported protocol by the same research group (Kim et al., 2020a). Briefly, pooled sperm sample was diluted with FSW at a ratio of $1: 10(\mathrm{v} / \mathrm{v})$. Cryoprotectant solution $\left(8 \% \mathrm{Me}_{2} \mathrm{SO}\right.$, $8 \%$ EG, 6\% PG, 2\% GLY, and 2\% MeOH) was prepared using newly prepared FSW. Diluted sperm were then gently mixed with cryoprotectant solution at an equal ratio. Sperm solution was then placed into straws $(0.25 \mathrm{~mL})$ and sealed with straw powder. Straws were placed in $5 \mathrm{~cm}$ rack height of a Styrofoam box (Length: $25.0 \mathrm{~cm} \times$ Width: $25.0 \mathrm{~cm} \times$ Height: $23 \mathrm{~cm}$ ) for
10 min. Subsequently, straws were immediately submersed in liquid nitrogen (LN) of Styrofoam box for at least $2 \mathrm{~h}$.

\section{Thawing of Cryopreserved Sperm}

Thawing temperature of $60^{\circ} \mathrm{C}$ has been previously recommended for cryopreserved sperm of Pacific abalone (Kim et al., 2020a). Thawing was accomplished in a digital water bath (JISICO Lab and Scientific Instrument, Seoul, South Korea). Straws were thawed at $60^{\circ} \mathrm{C}$ for $5 \mathrm{~s}$ using seawater in the water bath.

\section{Ion Channel Regulating Gene Expression Patterns in Cryopreserved Sperm}

\section{RNA Extraction and cDNA Synthesis}

Total RNAs were isolated from fresh and sperm cryopreserved with $8 \% \mathrm{Me}_{2} \mathrm{SO}, 8 \% \mathrm{EG}, 6 \% \mathrm{PG}, 2 \% \mathrm{GLY}$, or $2 \% \mathrm{MeOH}$ using an RNeasy mini kit (Qiagen, Hilden, Germany). RNasefree DNase (Promega, Madison, WI, United States) treatment was performed to eliminate contamination of genomic DNA. RNA concentration was then measured with a spectrophotometer (ACTGene ASP-2680, United States). For cDNA synthesis, total RNA was reverse transcribed using a Superscript ${ }^{\circledR}$ III First-Strand synthesis kit (Invitrogen, Carlsbad, CA, United States) following the manufacturer's procedure.

\section{Quantitative Real-Time PCR}

Quantitative PCR was performed to determine mRNA expression levels of PKA-C, HSP70, and HSP90 in fresh and cryopreserved sperm samples (8\% $\mathrm{Me}_{2} \mathrm{SO}, 8 \% \mathrm{EG}, 6 \% \mathrm{PG}, 2 \% \mathrm{GLY}$, and $2 \% \mathrm{MeOH}$ ). Gene-specific primers (Table 1) were designed to performed qRT-PCR. A $2 \times$ qPCRBIO SyGreen Mix Lo-Rox kit (PCR Biosystems, Ltd., London, United Kingdom) was used to conduct qRT-PCR as described by Sharker et al. (2020a). PCR amplification was conducted using a LightCycler ${ }^{\circledR} 96$ System (Roche, Germany) with a $20 \mu \mathrm{L}$ reaction containing $1 \mu \mathrm{L}$ cDNA template of each sperm sample, $10 \mu \mathrm{L}$ SyGreen Mix, $7 \mu \mathrm{L}$ PCR-grade water, and $1 \mu \mathrm{L}(10 \mathrm{pmol})$ of each forward and reverse primer. qRT-PCR of PKA-C gene was performed with the following cycling conditions: a pre-incubation step at $95^{\circ} \mathrm{C}$ for $2 \mathrm{~min}$, followed by 40 cycles of three-step amplification at $95^{\circ} \mathrm{C}$ for $30 \mathrm{~s}, 60^{\circ} \mathrm{C}$ for $30 \mathrm{~s}$, and $72^{\circ} \mathrm{C}$ for $15 \mathrm{~s}$. For qRT-PCRs of HSP70 and HSP90 genes, the following cycling conditions were used: a pre-incubation step at $95^{\circ} \mathrm{C}$ for $2 \mathrm{~min}$, followed by 40 cycles of a three-step amplification at $95^{\circ} \mathrm{C}$ for $5 \mathrm{~s}, 60^{\circ} \mathrm{C}$ for $15 \mathrm{~s}$, and $72^{\circ} \mathrm{C}$ for $20 \mathrm{~s}$. The following melting temperature was used as default settings: $95^{\circ} \mathrm{C}$ for $10 \mathrm{~s}, 65^{\circ} \mathrm{C}$ for $1 \mathrm{~min}$, and $97^{\circ} \mathrm{C}$ for $1 \mathrm{~min}$. Fluorescence reading was performed at the end step of each cycle for quantification. The relative mRNA expression was quantified using the $2^{-\Delta \Delta \mathrm{Ct}}$ method (Livak and Schmittgen, 2001). $\beta$-actin, a house keeping gene, was also amplified for each sample for normalization.

\section{Fluorescent Technique to Assess Post Thaw Sperm Quality} Acrosome Integrity Test

Acrosome integrity was accessed using LYSO-G/PI method ${ }^{\circledR}$ according to the protocol described by Kim et al. (2020a) with 
TABLE 1 | List of primers used for qRT-PCR quantification of gene in sperm.

\begin{tabular}{|c|c|c|c|c|}
\hline Gene & Primer & Sequence & Amplicon length (bp) & References \\
\hline \multirow[t]{2}{*}{ Hdh- $\beta$-Actin } & Sense & 5'-CCGTGAAAAGATGACCCAGA-3' & 204 & Ma et al., 2004 \\
\hline & Antisense & 5'-TACGACCGGAAGCGTACAGA-3' & & \\
\hline \multirow[t]{2}{*}{ PKA-C } & Sense & 5'-AGCCAGCAGTTGCAAATGC-3' & 199 & Kong et al., 2020 \\
\hline & Antisense & 5'-CTTCTCATITAATGTGTGCTCC-3' & & \\
\hline \multirow[t]{2}{*}{ HSP70 } & Sense & 5'-CAGAGAACACAATCTTCGATGC-3' & 277 & Cheng et al., 2007 \\
\hline & Antisense & 5'-CGTTGAGAGTCGTTGAAGTAAG-3' & & \\
\hline \multirow[t]{2}{*}{ HSP90 } & Sense & 5'-AACAGTACATCTGGGAGTCG-3' & 216 & Zhang et al., 2011 \\
\hline & Antisense & 5'-ССTCСТTGTCTCTाTCСТTСТ-3' & & \\
\hline
\end{tabular}

slightly modifications. Briefly, sperm samples were diluted with PBS to a concentration of $1 \times 10^{6}$ cells $/ \mathrm{mL}$. Sperm number was counted using a hemacytometer (Paul Marienfeld GmbH \& Co., Germany). LYSO-G and PI were incubated at $37^{\circ} \mathrm{C}$ for $10 \mathrm{~min}$ in the dark. After that, $5 \mu \mathrm{L}(1 \mathrm{mM})$ of LYSO-G and $10 \mu \mathrm{L}(2.4 \mathrm{mM})$ of PI were gently mixed with $500 \mu \mathrm{L}$ samples and incubated at $37^{\circ} \mathrm{C}$ for $30 \mathrm{~min}$ in the dark. Sperm sample $(2 \mu \mathrm{L})$ was placed on a slide and enclosed with a cover slip. Stained sample was immediately visualized under a fluorescent microscope (Nikon eclipse E600). A green filter (B-2A; excitation filter 450-490 nm) was used to capture LYSO-G-stained intact acrosome (LYSO$\mathrm{G}^{+} / \mathrm{PI}^{-}$). A red filter (G-2A; emission filter 510-560 nm) was used to capture PI-stained damaged acrosome (LYSO-G ${ }^{-} / \mathrm{PI}^{+}$). Pictures taken with green and red filters were merged with image captured without a filter to detect AI of post thawed sperm. NIS software program was used to analyze the percent value of AI $(n=6)$.

\section{Plasma Membrane Integrity Test}

The integrity of plasma membrane was observed using LIVE/DEAD ${ }^{\circledR}$ sperm viability kit by slightly adjusting the protocol described by Kim et al. (2020a). Briefly, sample was gently diluted with PBS to a concentration of $1 \times 10^{6}$ cells $/ \mathrm{mL}$. A $5 \mu \mathrm{L}$ aliquot of SYBR ${ }^{\mathrm{TM}} 14(1 \mathrm{mM}$ of dye in $100 \mu \mathrm{L}$ of $\mathrm{Me}_{2} \mathrm{SO}$ ) was gently mixed with $1 \mathrm{~mL}$ sample and incubated at $36^{\circ} \mathrm{C}$ for $10 \mathrm{~min}$ in the dark. After that, $5 \mu \mathrm{L}$ of PI was gently mixed with sample and again incubated at $36^{\circ} \mathrm{C}$ for $10 \mathrm{~min}$ in the dark. Samples $(2 \mu \mathrm{L})$ were immediately placed on glass slides and observed under a fluorescent microscope (Nikon Eclipse E600). SYBR14 stained images of intact plasma membranes (SYBR14 ${ }^{+} / \mathrm{PI}^{-}$) were captured using a green filter. Damaged plasma membranes $\left(\mathrm{SYBR} 14^{-} / \mathrm{PI}^{+}\right)$stained with PI were captured using a red filter. Visualization and analysis $(n=6)$ were accomplished according to method described in the previous section (“Acrosome Integrity Test”).

\section{Mitochondrial Membrane Potential Test}

Mitochondrial membrane potentials of post thawed sperm samples were assessed using $\mathrm{Rh} 123 / \mathrm{PI}^{\circledR}$ by partially modifying the method described by Kim et al. (2020a). Briefly, $0.8 \mu \mathrm{L}$ of Rh123 (13 mM) was appropriately mixed with $1 \mathrm{~mL}$ sample $\left(1 \times 10^{6}\right.$ cells $\left./ \mathrm{mL}\right)$ and incubated at $20^{\circ} \mathrm{C}$ for $10 \mathrm{~min}$ in the dark. Subsequently, $5 \mu \mathrm{L}(2.4 \mathrm{mM})$ aliquot of PI was gently mixed with the sample and again incubated at $20^{\circ} \mathrm{C}$ for $10 \mathrm{~min}$ in

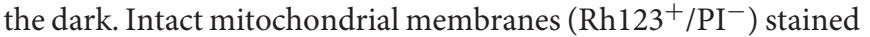
with Rh123 were captured using a green filter. A red filter was used to capture PI-stained damaged mitochondrial membranes

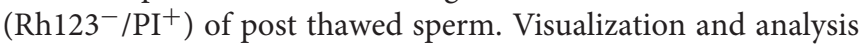
$(n=6)$ were accomplished according to the method described in Section "Acrosome Integrity Test."

\section{Morphological Evaluation of Sperm}

Fluorescent technique was applied to evaluate morphological characteristics (AI, PMI, and MMP) of fresh and cryopreserved sperm according to the method described by Kim et al. (2020b). Sperm structure was visualized under a fluorescent microscope $(100 \times)$. Six replications were conducted from each treatment and a minimum of 200 sperm were evaluated for each replication.

\section{Sperm DNA Integrity Test}

Sperm DNA integrity was assessed using Comet assay ${ }^{\circledR}$ kit by slightly modifying the protocol described by Kim et al. (2020b). Briefly, sperm sample was suspended with pre-chilled PBS (1X) at a concentration of $1 \times 10^{5}$ cells $/ \mathrm{mL}$. Sperm was immobilized in comet agarose on comet slides ${ }^{\text {TM }}$. Slides were treated with chilled lysis buffer for $1 \mathrm{~h}$ and then treated with an alkaline unwinding solution for another $1 \mathrm{~h}$. Subsequently, slides were electrophoresed for $30 \mathrm{~min}$ at $21 \mathrm{~V}$ with an electrophoresis solution. Slides were washed using $\mathrm{DI} \mathrm{H}_{2} \mathrm{O}$ for $10 \mathrm{~min}$ and stained with Vista green DNA dye. Stained samples were immediately observed under a fluorescence microscope (excitation filter 450-490 nm, Nikon eclipse E600) to capture comet pictures. A minimum of 100 comets were analyzed from each treatment. Several indicators of sperm DNA integrity such as head length, tail length, \% DNA in head, \% DNA in tail, and tail moment of comets were analyzed using a comet Assay IV image analysis software (version 4.3.2, Perceptive Instruments Ltd., United Kingdom).

\section{Fertility and Hatchability Test Collection of Egg and Quality Observation}

Good quality females were chosen from the rearing tank and exposed to sunlight for $1 \mathrm{~h}$ with shell facing down and another 30 min with muscle facing down. Abalone were then transferred to inducing buckets. For each bucket, $2 / 3$ portion was filled up with UV-treated water. Seawater was UV-treated and its temperature was maintained at $2^{\circ} \mathrm{C}$ more than the temperature of the rearing tank water. Abalone were induced for a period of 
1-5 $\mathrm{h}$ with continuous aeration. During inducing, abalone were checked at $1 \mathrm{~h}$ intervals with water changed. After spawning, egg quality was observed under a microscope (Nikon eclipse E200) to evaluate the envelop shape, nucleus shape, and egg color.

\section{Determination of Suitable Sperm to Egg Ratio for in vitro Fertilization}

Sperm to egg ratios of 1,000:1, 2,500:1, 5,000:1, 10,000:1, 20,000:1, $30,000: 1,40,000: 1$, and 50,000:1 were used to find the suitable ratio for fertilization and hatching. A series of ceramic bowls $(500 \mathrm{~mL})$ were used to conduct the fertilization experiment. In each experimental bowl, 40,000 eggs were used for the fertilization experiment. Three replications were conducted from each combination. Sperm were gently mixed with eggs for proper fertilization. Fertilization and hatching were observed under a microscope (Nikon eclipse E200). Fertilized eggs were washed three times using FSW. The water temperature in experimental bowl was maintained at $18-20^{\circ} \mathrm{C}$. Fertilization rate was $(n=3)$ calculated based on $2 \mathrm{~h}$ post fertilized embryo of Pacific abalone. Hatching rate was analyzed $(n=3)$ based on $16 \mathrm{~h}$ post fertilized veliger larvae of Pacific abalone. Fertilization rate and hatching rate were calculated using the following formulas:

Fertilization rate $(\%)=$ Number of fertilized egg/number of eggs counted $\times 100$.

Hatching rate $(\%)=$ Number of $16 \mathrm{~h}$ hatched larvae/number of fertilized eggs $\times 100$.

\section{Fertilization and Hatching Rate of Cryopreserved Sperm}

Sperm cryopreserved with $8 \% \mathrm{Me}_{2} \mathrm{SO}$ and $2 \%$ GLY were used in in vitro fertilization to check fertilization and hatching rates of cryopreserved sperm. Straws were thawed at $60^{\circ} \mathrm{C}$ and used for fertilization of eggs. Sperm to egg ratio was fixed based on the results of the previous section. Fertilization $(n=3)$ and hatching rates $(n=3)$ were calculated based on the equation described in the previous section. Water temperatures of experimental buckets were maintained at $18-20^{\circ} \mathrm{C}$. After fertilization, eggs were washed three times (30 min for each wash) using FSW at $18-20^{\circ} \mathrm{C}$.

\section{Statistical Analysis}

Statistical data were analyzed using SPSS 16.00 (SPSS Inc., Chicago, IL, United States). Data are presented as mean and standard deviation (SD). One-way analysis of variance (ANOVA) was performed to present experimental results as mean \pm SD. Duncan's multiple range test was used to determine differences between multiple groups. Differences were considered statistically significant at $p<0.05$. Pearson correlation analysis was performed to determine relationships among sperm quality parameters. A GraphPad Prism 5.1 software (GraphPad Prism version 5.00 for Windows; GraphPad Software, San Diego, CA, United States) was used to generate graphs.

\section{RESULTS}

\section{Ion Composition of Seminal Plasma}

Results of osmolarity, $\mathrm{pH}$, and ion concentrations of Pacific abalone seminal plasma are shown in Table 2. Seminal plasma $\mathrm{pH}(6.8 \pm 0.1)$ of Pacific abalone was neutral with an osmolarity of $1,126 \pm 3 \mathrm{mOsmL}^{-1}$. Two ions, $\mathrm{Na}^{+}(459.1 \pm 3.1 \mathrm{mM})$ and $\mathrm{Cl}^{-}(515.9 \pm 1.1 \mathrm{mM})$, were predominant in the seminal plasma, following by other ions.

\section{Gene Expression in Cryopreserved Sperm Expression of PKA-C}

Protein kinase A mRNA expression levels in post thaw sperm were significantly $(p<0.05)$ decreased than those in fresh sperm (Figure 1). Sperm cryopreserved with $8 \%$ $\mathrm{Me}_{2} \mathrm{SO}$ showed higher expression levels of PKA-C mRNA than other post thaw sperm samples. However, PKA-C mRNA expression pattern did not show significant difference $(p>0.05)$ between sperm cryopreserved with $8 \% \mathrm{Me}_{2} \mathrm{SO}$ and sperm cryopreserved with $8 \%$ EG.

\section{Expression of HSP70}

Relative mRNA expression levels of HSP70 in fresh and cryopreserved sperm samples are shown in Figure 2. Fresh sperm showed significantly $(p<0.05)$ higher mRNA expression level of HSP70 than cryopreserved sperm samples. Sperm cryopreserved with $8 \% \mathrm{Me}_{2} \mathrm{SO}$ had higher HSP70 mRNA expression than sperm cryopreserved with $8 \%$ EG, 6\% PG, 2\% GLY, or 2\% $\mathrm{MeOH}$. However, mRNA expression level showed significant similarity between sperm cryopreserved using $8 \% \mathrm{Me}_{2} \mathrm{SO}$, $8 \% \mathrm{EG}$, or $2 \%$ GLY.

\section{Expression of HSP90}

Relative mRNA expression levels of HSP90 in fresh and five types of post thaw sperm samples were quantified by qRT-PCR (Figure 3). Fresh sperm sample showed significantly $(p<0.05)$ higher HSP90 mRNA expression levels than cryopreserved sperm samples. Sperm cryopreserved with $8 \% \mathrm{Me}_{2} \mathrm{SO}$ showed higher HSP90 expression than other cryopreserved sperm samples. The expression level of HSP90 did not show significant differences

TABLE 2 | Seminal plasma compositions of Pacific abalone, $H$. discus hannai $(n=20)$.

\begin{tabular}{lc}
\hline Parameters of seminal plasma & Mean \pm SD \\
\hline Osmolarity $\left(\mathrm{mOsm} \mathrm{L}^{-1}\right)$ & $1,126.0 \pm 3.0$ \\
$\mathrm{pH}$ & $6.8 \pm 0.1$ \\
$\mathrm{Na}^{+}(\mathrm{mM})$ & $459.1 \pm 3.1$ \\
$\mathrm{~K}^{+}(\mathrm{mM})$ & $15.6 \pm 0.1$ \\
$\mathrm{Mg}^{2+}(\mathrm{mM})$ & $52.8 \pm 0.2$ \\
$\mathrm{Ca}^{2}(+(\mathrm{mM})$ & $10.3 \pm 0.1$ \\
$\mathrm{Cl}^{-}(\mathrm{mM})$ & $515.9 \pm 1.1$ \\
$\mathrm{SO}_{4}{ }^{2-}(\mathrm{mM})$ & $45.3 \pm 0.2$ \\
$\mathrm{Br}^{-}(\mathrm{mM})$ & $17.9 \pm 0.1$ \\
$\mathrm{~F}^{-}(\mathrm{mM})$ & $2.7 \pm 0.2$
\end{tabular}




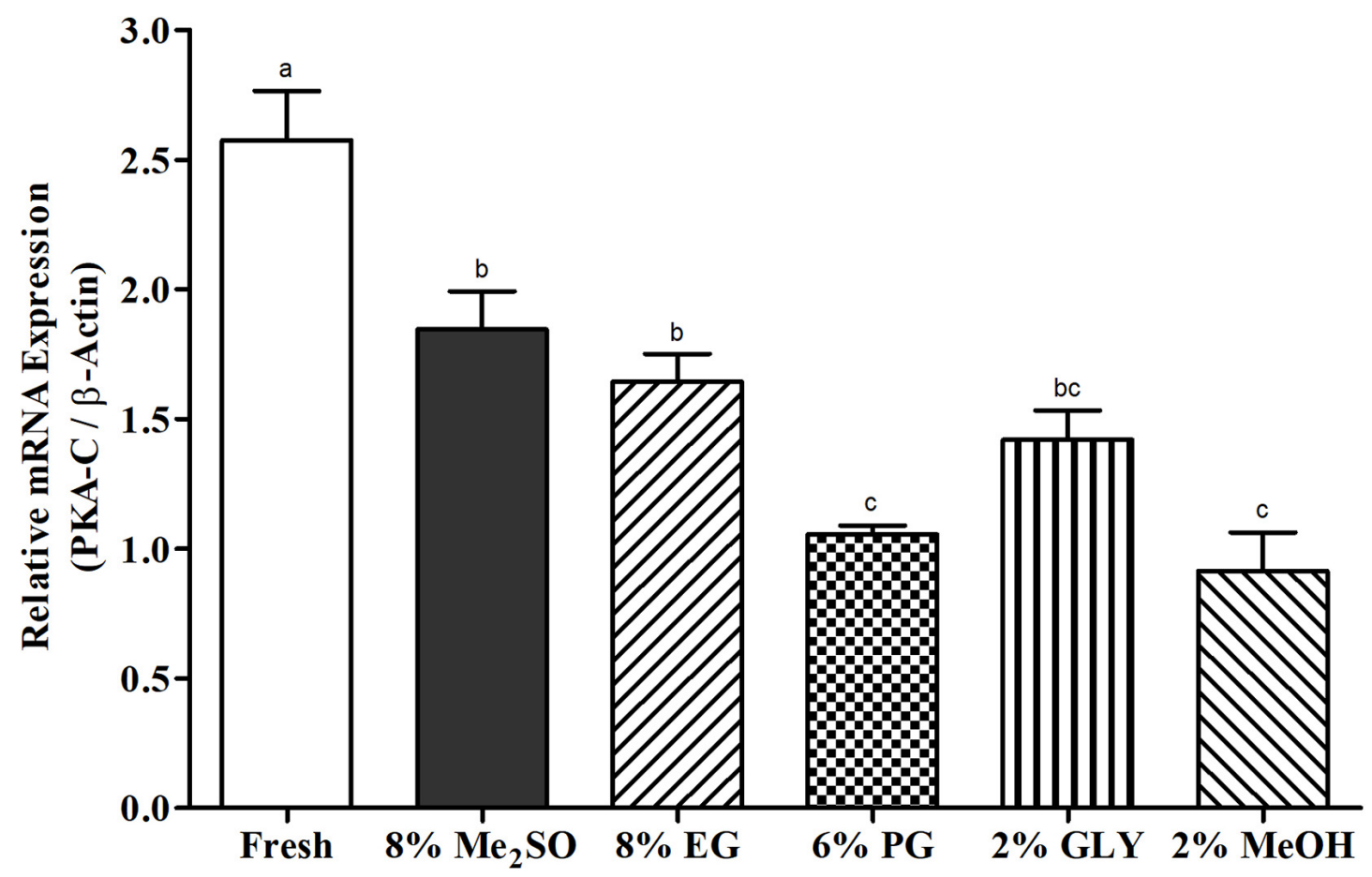

FIGURE 1 | PKA-C mRNA expression levels in fresh and cryopreserved sperm samples $(n=3)$ of Pacific abalone, $H$. discus hannai. Expression values of PKA-C mRNA were normalized against average $\Delta$ CT values of control. Different superscript letters $(a-c)$ above bars indicate significant $(p<0.05)$ differences between fresh and cryopreserved sperm samples.

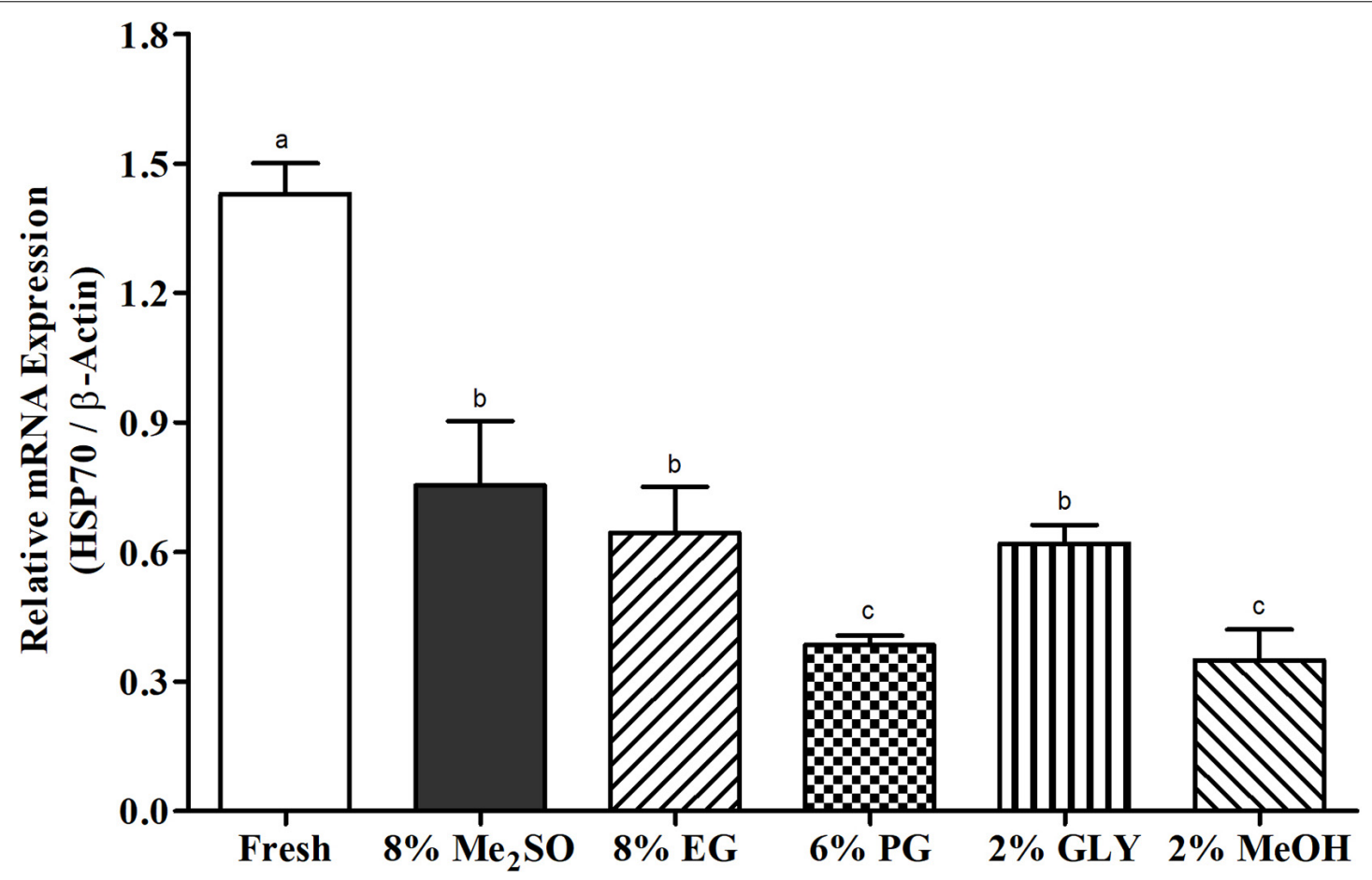

FIGURE 2 | HSP70 mRNA expression levels in fresh and cryopreserved sperm samples $(n=3)$ of Pacific abalone, $H$. discus hannai. Expression values of HSP70 mRNA were normalized against average $\Delta$ CT values of control. Different superscript letters (a-c) above bars indicate significant $(p<0.05)$ differences between fresh and cryopreserved sperm samples. 


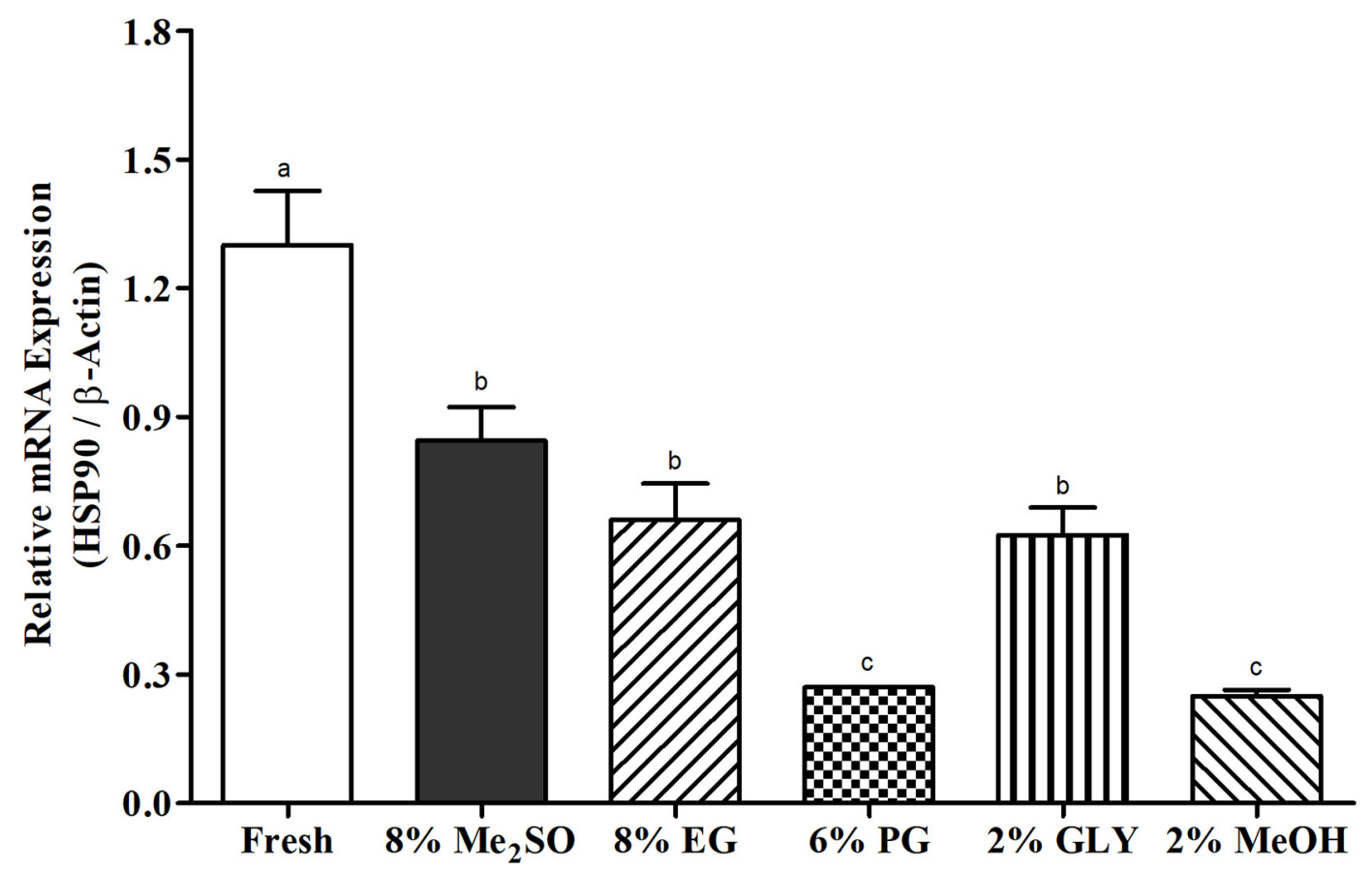

FIGURE 3 | HSP90 mRNA expression levels in fresh and cryopreserved sperm samples $(n=3)$ of Pacific abalone, $H$. discus hannai. Expression values of HSP90 mRNA were normalized against average $\Delta$ CT values of control. Different superscript letters $(a-c)$ above bars indicate significant $(p<0.05)$ differences between fresh and cryopreserved sperm samples.

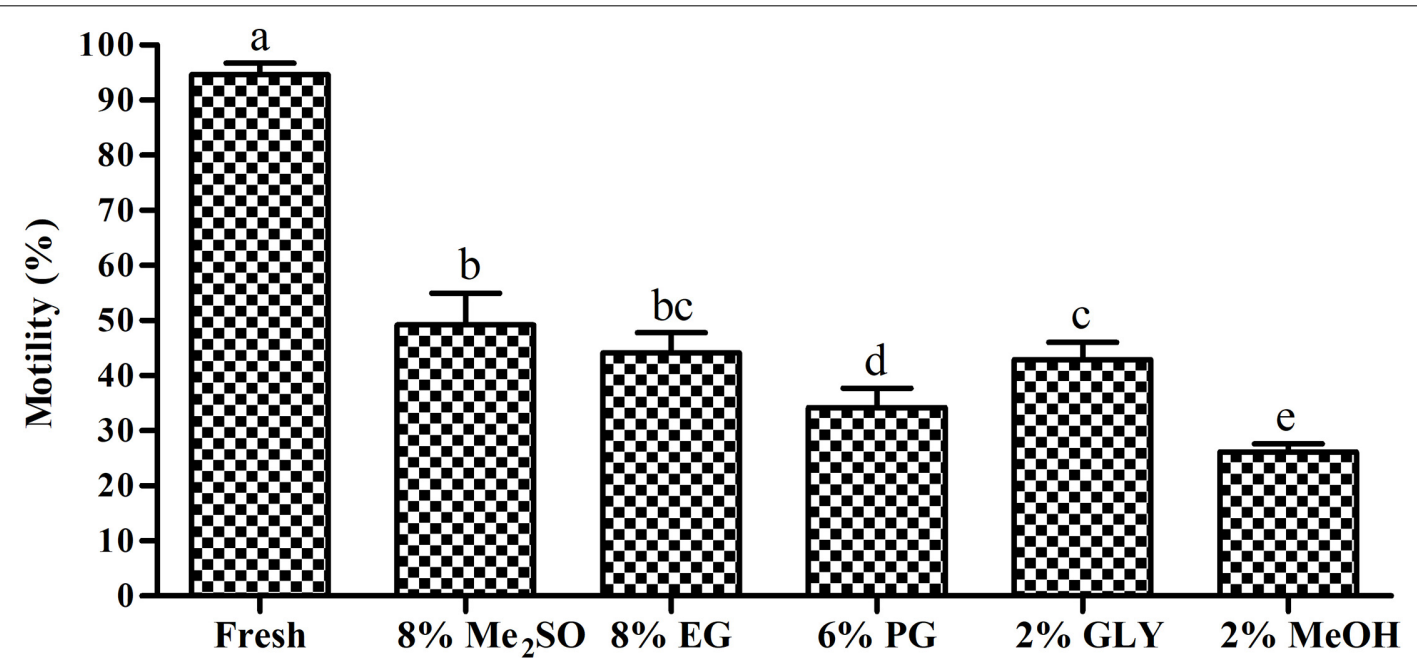

FIGURE 4 | Post thaw sperm motility of Pacific abalone, H. discus hannai. Results are expressed as mean \pm standard deviation of mean (SD) ( $n=6)$. Significant $(p<0.05)$ differences between different groups are indicated by superscript letters $(a-c)$.

for sperm cryopreserved with $8 \% \mathrm{Me}_{2} \mathrm{SO}, 8 \% \mathrm{EG}$, or $2 \%$ GLY $(p>0.05)$.

\section{Post Thaw Sperm Motility}

Sperm cryopreserved with $8 \% \mathrm{Me}_{2} \mathrm{SO}$ revealed highest post thaw sperm motility $(50.0 \pm 5.0 \%)$ compared with other CPA solution (Figure 4). It showed significant differences $(p<0.05)$ with fresh sperm motility $(94.7 \pm 2.1 \%)$.

\section{Acrosome Integrity (Al)}

Acrosome integrity was assessed for post thawed sperm cryopreserved with three types of CPA (8\% EG, 6\% PG, and $2 \% \mathrm{MeOH}$ ). AI value of sperm cryopreserved with $8 \%$ EG was $48.0 \pm 2.2 \%$, higher than AI values of sperm cryopreserved with other CPA solutions, but significantly $(p<0.05)$ lower than AI value of fresh sperm (Figure 5 and Table 3). On the other hand, AI value of sperm cryopreserved with $6 \%$ PG 


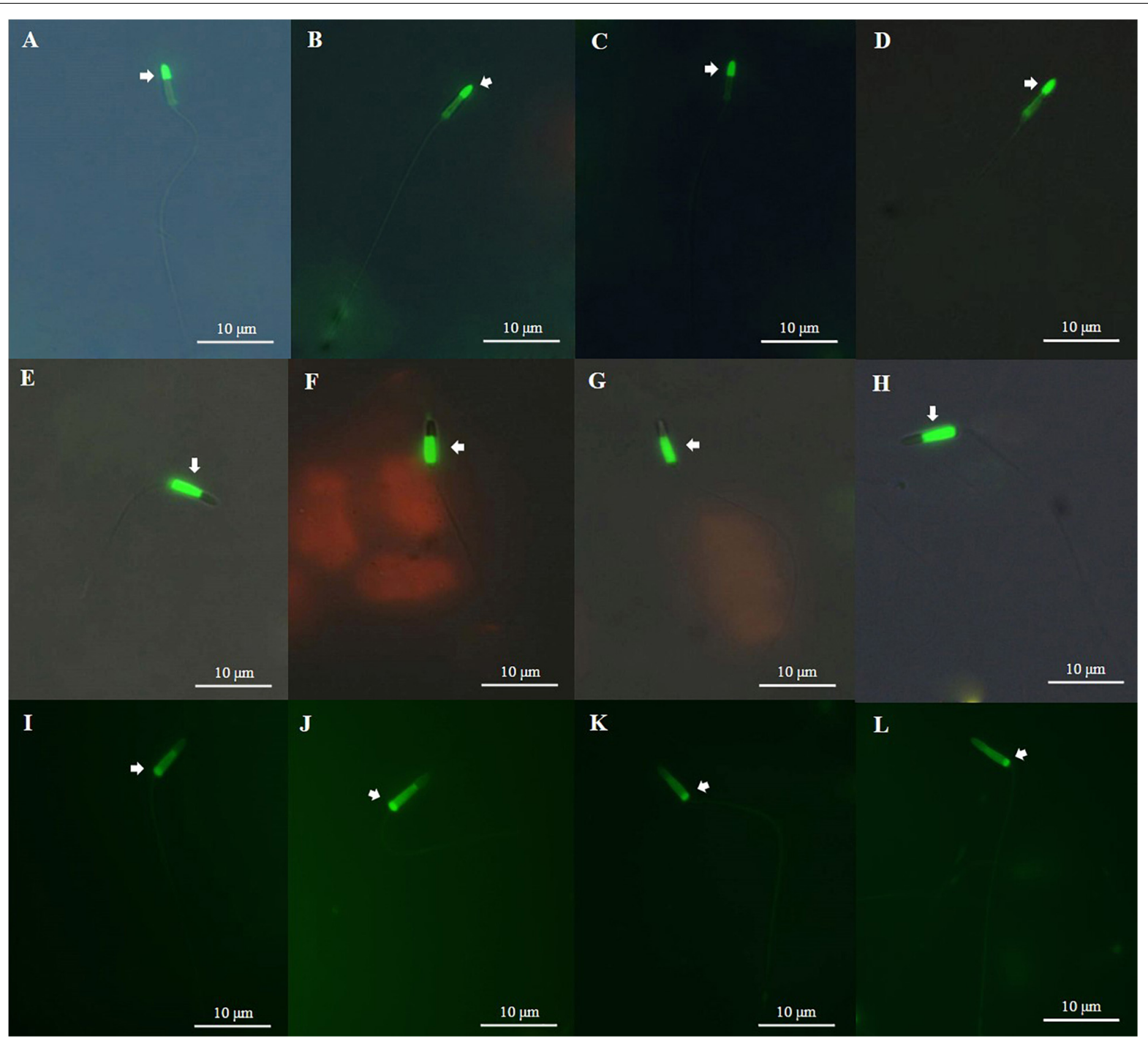

FIGURE 5 | Fluorescently stained photographs of Pacific abalone sperm. (A) Acrosome integrity (Al) of fresh sperm; (B) Al of sperm cryopreserved with 8\% ethylene glycol (EG); (C) Al of sperm cryopreserved with 6\% propylene glycol (PG); (D) Al of sperm cryopreserved with 2\% MeOH; (E) plasma membrane integrity (PMI) of fresh sperm; (F) PMI of sperm cryopreserved with 8\% EG; (G) PMI of sperm cryopreserved with 6\% PG; (H) PMI of sperm cryopreserved with 2\% MeOH; (I) mitochondrial membrane potential (MMP) of fresh sperm; (J) MMP of sperm cryopreserved with 8\% EG; (K) MMP of sperm cryopreserved with 6\% PG; and (L) MMP of sperm cryopreserved with $2 \% \mathrm{MeOH}$.

was not significantly $(p>0.05)$ different from that of sperm cryopreserved with $2 \% \mathrm{MeOH}$.

\section{Plasma Membrane Integrity}

Results of PMI of fresh and cryopreserved sperm are shown in Table 3 and Figure 5. PMI value of sperm cryopreserved with $8 \%$ EG was $50.5 \pm 4.0 \%$, which was significantly $(p<0.05)$ higher than PMI values of sperm cryopreserved with other CPA solutions, but significantly $(p<0.05)$ lower than the PMI of fresh sperm $(96.0 \pm 0.7 \%)$.

\section{Mitochondrial Membrane Potential}

Mitochondrial membrane potential value of sperm cryopreserved with $8 \%$ EG was $39.4 \pm 1.6 \%$, which was significantly $(p<0.05)$ higher than MMP values of sperm cryopreserved with other CPA solutions, but significantly $(p<0.05)$ lower than the MMP value of fresh sperm $(94.1 \pm 1.6 \%)$. Sperm cryopreserved with $2 \%$ $\mathrm{MeOH}$ represented significantly lower $(p>0.05) \mathrm{MMP}$ than other cryoprotectants (Table 3 and Figure 5).

\section{Morphological Evaluation of Sperm}

Morphological characteristics of fresh and cryopreserved sperm are presented in Table 4 and Figure 6. Cryopreservation reduced the number of normal sperm from $87.6 \pm 1.2$ to $29.4 \pm 4.5 \%$. Sperm cryopreserved with $2 \% \mathrm{MeOH}$ showed higher percentage (70.6\%) of defect than sperm cryopreserved with other CPA solutions and fresh sperm. Among different categories of defects, total structure damage, abnormal body shape, coiled tail, and 
TABLE 3 | Comparison of plasma membrane integrity (PMI), mitochondrial potential (MP), and acrosome integrity (Al) between fresh and cryopreserved sperm (mean $\pm \mathrm{SD})(n=6)$.

\begin{tabular}{lccc}
\hline Cryoprotectant solution & PMI (\%) & MP (\%) & Al (\%) \\
\hline Fresh sperm & $96.0 \pm 0.7^{\mathrm{a}}$ & $94.1 \pm 1.6^{\mathrm{a}}$ & $95.8 \pm 0.7^{\mathrm{a}}$ \\
$8 \% \mathrm{EG}$ & $50.5 \pm 4.0^{\mathrm{b}}$ & $39.4 \pm 1.6^{\mathrm{b}}$ & $48.0 \pm 2.2^{\mathrm{b}}$ \\
$6 \% \mathrm{PG}$ & $31.2 \pm 1.7^{\mathrm{c}}$ & $24.4 \pm 0.9^{\mathrm{c}}$ & $28.7 \pm 2.1^{\mathrm{c}}$ \\
$2 \% \mathrm{MeOH}$ & $28.1 \pm 2.7^{\mathrm{c}}$ & $20.8 \pm 1.5^{\mathrm{d}}$ & $27.4 \pm 2.5^{\mathrm{c}}$
\end{tabular}

Significant different levels $(p<0.05)$ are denoted by different letters.

droplet in tail were not observed for fresh sperm. Total structure damage was the leading defect in all types of cryopreserved sperm ( $8 \% \mathrm{Me}_{2}$ SO: $17 \pm 1.5 \%$, 8\% EG: $18 \pm 2.8 \%, 6 \%$ PG\%: $29.8 \pm 3.1 \%$, 2\% GLY: $25.8 \pm 2.8 \%$, and $2 \% \mathrm{MeOH}: 32.8 \pm 3.6 \%$ ).

\section{Sperm DNA Integrity}

Results of comet assay parameters of fresh and cryopreserved sperm are presented in Table 5 and Figure 7. DNA integrity of sperm cryopreserved with $8 \% \mathrm{Me}_{2} \mathrm{SO}$ was $63.8 \pm 6.8 \%$, not significantly $(p>0.05)$ different from that of sperm cryopreserved with $2 \%$ GLY $(60.1 \pm 9.0 \%)$. DNA fragmentation of sperm cryopreserved with $6 \%$ PG was $73.8 \pm 3.4 \%$, higher than that of sperm cryopreserved with any other CPA solution or fresh sperm $(3.2 \pm 0.6 \%)$.

\section{Correlation Between Sperm Quality Parameters}

Sperm motility shed strongly positive correlations (Table 6) with AI $(r=0.990 ; p<0.01)$, PMI $(r=0.989 ; p<0.01)$, MMP $(r=0.992 ; p<0.01)$, and fertilization $(r=0.989 ; p<0.01)$. However, DNA fragmentation was negatively correlated with motility $(r=-0.958 ; p<0.01)$, AI $(r=-0.929 ; p<0.01)$, PMI $(r=-0.922 ; p<0.01)$, MMP $(r=-0.931 ; p<0.01)$, and fertilization $(r=-0.983 ; p<0.01)$.

\section{Fertility and Hatchability Test Determination of Suitable Sperm to Egg Ratio for in vitro Fertilization}

Fertilization and hatching rates for eight different sperm to egg ratios are presented in Figure 8. Sperm to egg ratio of $10,000: 1$ resulted in the highest fertilization rate $(73.1 \pm 3.9 \%)$ and hatching rate $(68.2 \pm 5.5 \%)$, not significantly $(p>0.05)$ different from sperm to egg ratio of 20,000:1 (Figure 8). Both high $(50,000: 1)$ and low $(1,000: 1)$ sperm to egg ratios resulted in significantly lower fertilization and hatching rates $(p<0.05)$ than a sperm to egg ratio of $10,000: 1$ or $20,000: 1$.

\section{Fertilization and Hatching Rate of Cryopreserved Sperm}

The sperm to egg ratio of 10,000:1 was selected based on the results of previous section (section "Determination of Suitable Sperm to Egg Ratio for in vitro Fertilization"). Fertilization rate did not show any significant difference $(p>0.05)$ between sperm cryopreserved with $8 \% \mathrm{Me}_{2} \mathrm{SO}(31.4 \pm 3.2 \%)$ and those cryopreserved with $2 \%$ GLY $(29.6 \pm 0.5 \%)$. However, hatching rate showed significant $(p<0.05)$ differences between sperm cryopreserved with $8 \% \mathrm{Me}_{2} \mathrm{SO}$ and those cryopreserved with $2 \%$ GLY (Figure 9).

\section{DISCUSSION}

The present study investigated effects of cryopreservation on ion channel regulating gene expression and post thaw sperm quality of Pacific abalone. This research group has previously been documented suitable equilibration time, post thaw motility, rack height, straw effect, and thawing temperature for sperm cryopreservation of this commercial valuable species (Kim et al., 2020a). They recommend five types of CPAs with suitable concentration (8\% $\mathrm{Me}_{2} \mathrm{SO}, 8 \% \mathrm{EG}, 6 \% \mathrm{PG}, 2 \% \mathrm{GLY}$, and $2 \%$ $\mathrm{MeOH})$. However, they only reported sperm viability results for sperm cryopreserved with $8 \% \mathrm{Me}_{2} \mathrm{SO}$ and $2 \%$ GLY. Evaluating post thaw quality of sperm cryopreserved with all CPAs is essential to find the most suitable cryopreservation technique

TABLE 4 | Cryo-defects of sperm cryopreserved with different types of cryoprotectants.

\begin{tabular}{|c|c|c|c|c|c|c|}
\hline \multirow[t]{2}{*}{ Sperm characteristics } & \multicolumn{6}{|c|}{ Percentage (Mean \pm SD) } \\
\hline & Fresh sperm & $8 \% \mathrm{Me}_{2} \mathrm{SO}$ & $8 \%$ EG & $6 \% \mathrm{PG}$ & $2 \%$ GLY & $2 \% \mathrm{MeOH}$ \\
\hline Normal shape & $87.6 \pm 1.2^{\mathrm{a}}$ & $53.7 \pm 3.6^{b}$ & $48.5 \pm 3.5^{\mathrm{c}}$ & $36.1 \pm 4.6^{d}$ & $46.2 \pm 4.3^{\mathrm{C}}$ & $29.4 \pm 4.5^{f}$ \\
\hline Total structure damage & 0.0 & $17 \pm 1.5^{9}$ & $18 \pm 2.8^{9}$ & $29.8 \pm 3.1^{f}$ & $25.8 \pm 2.8^{f}$ & $32.8 \pm 3.6^{\mathrm{e}}$ \\
\hline Acrosome defect & $1.8 \pm 0.2^{\text {no }}$ & $7.4 \pm 1.6 \mathrm{j}^{\mathrm{jk}}$ & $7.1 \pm 2.0^{\mathrm{ijk}}$ & $6.4 \pm 1.1^{i j}$ & $6.6 \pm 1.4^{\mathrm{ijk}}$ & $14.9 \pm 1.6^{9}$ \\
\hline Detached head & $1.6 \pm 0.4^{\text {no }}$ & $2.8 \pm 0.8^{\mathrm{lm}}$ & $1 \pm 0.2^{\text {no }}$ & $5.7 \pm 1.0^{\mathrm{ijk}}$ & $1.6 \pm 0.5^{\text {no }}$ & $4.2 \pm 1.2^{\mathrm{jk}}$ \\
\hline Short tail & $2.8 \pm 0.4^{\mathrm{Im}}$ & $3.9 \pm 0.5^{\mathrm{jkl}}$ & $3 \pm 0.6^{\mathrm{Im}}$ & $2.8 \pm 0.3^{\mathrm{Im}}$ & $2.8 \pm 0.5^{\mathrm{Im}}$ & $3.1 \pm 0.4^{\mathrm{Im}}$ \\
\hline Abnormal body shape & 0.0 & $4.3 \pm 0.6^{\mathrm{jk}}$ & $4.2 \pm 0.9^{j \mathrm{kl}}$ & $6 \pm 1.4^{i j k}$ & $5.1 \pm 0.8^{j k}$ & $4.8 \pm 1.4^{j \mathrm{k}}$ \\
\hline Broken tail & $2.3 \pm 0.3^{\mathrm{mn}}$ & $4.1 \pm 0.4^{j \mathrm{kl}}$ & $2.5 \pm 0.6^{\mathrm{mn}}$ & $0.8 \pm 0.7^{\circ}$ & $7.2 \pm 1.2^{\mathrm{ijk}}$ & $3.5 \pm 1.1^{\mathrm{kl}}$ \\
\hline Neck folding & $3.8 \pm 0.3^{\mathrm{kl}}$ & $6.8 \pm 0.7^{\mathrm{ijkl}}$ & $10.4 \pm 1.7^{h}$ & $8.8 \pm 1.6^{\mathrm{hi}}$ & $4.7 \pm 0.9^{j k}$ & $6.3 \pm 0.9^{\mathrm{ijk}}$ \\
\hline Coiled tail & 0.0 & 0.0 & $2.2 \pm 0.3^{\mathrm{mn}}$ & $2 \pm 0.2^{m n}$ & 0.0 & 0.0 \\
\hline Droplet in tail & 0.0 & 0.0 & $3.1 \pm 0.6^{\mathrm{lm}}$ & $1.6 \pm 0.7^{\mathrm{no}}$ & 0.0 & $1 \pm 0.2^{\text {no }}$ \\
\hline
\end{tabular}

Significant different levels $(p<0.05)$ are denoted by different letters. 


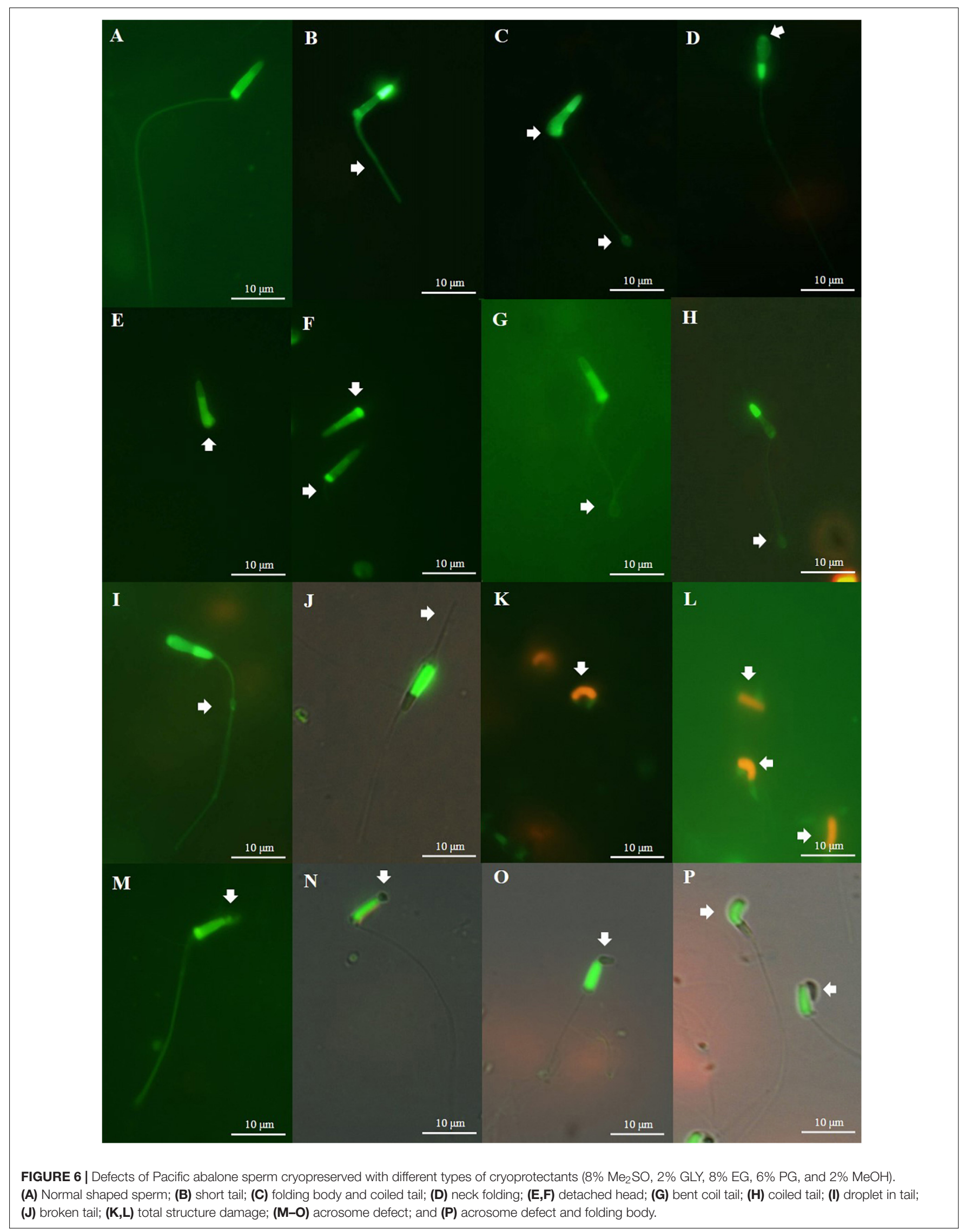


TABLE 5 | Comet assay parameters (mean \pm standard deviation) of fresh and cryopreserved sperm samples of $H$. discus hannai.

\begin{tabular}{|c|c|c|c|c|c|c|}
\hline Parameters & Fresh sperm & $8 \% \mathrm{Me}_{2} \mathrm{SO}$ & $8 \%$ EG & $6 \%$ PG & $2 \%$ GLY & $2 \% \mathrm{MeOH}$ \\
\hline Head length $(\mu)$ & $35.4 \pm 10.2^{d}$ & $52.5 \pm 6.8^{a}$ & $35.9 \pm 8.6^{d}$ & $33.6 \pm 8.5^{d}$ & $49.9 \pm 4.5^{b}$ & $44.0 \pm 7.8^{c}$ \\
\hline$\%$ DNA in head & $96.8 \pm 3.2^{a}$ & $63.8 \pm 6.8^{b}$ & $49.9 \pm 4.3^{c}$ & $26.2 \pm 3.3^{\mathrm{e}}$ & $60.1 \pm 9.0^{b}$ & $33.1 \pm 4.9^{d}$ \\
\hline Tail length $(\mu)$ & $19.98 \pm 4.6^{e}$ & $49.32 \pm 7.2^{d}$ & $70.9 \pm 5.9^{c}$ & $147.2 \pm 22.8^{a}$ & $114.4 \pm 27.1^{b}$ & $121.2 \pm 17.9^{b}$ \\
\hline$\%$ DNA in tail & $3.2 \pm 0.6^{e}$ & $36.2 \pm 6.9^{d}$ & $50.1 \pm 4.3^{C}$ & $73.8 \pm 3.4^{a}$ & $39.9 \pm 9.0^{d}$ & $66.9 \pm 4.9^{b}$ \\
\hline Tail moment $(\mu)$ & $0.5 \pm 0.1^{d}$ & $17.7 \pm 2.4^{\mathrm{c}}$ & $18.6 \pm 3.4^{\mathrm{c}}$ & $63.0 \pm 7.6^{\mathrm{a}}$ & $21.3 \pm 3.5^{c}$ & $42.6 \pm 5.8^{b}$ \\
\hline
\end{tabular}

Significant different levels $(p<0.05)$ are denoted by different letters.

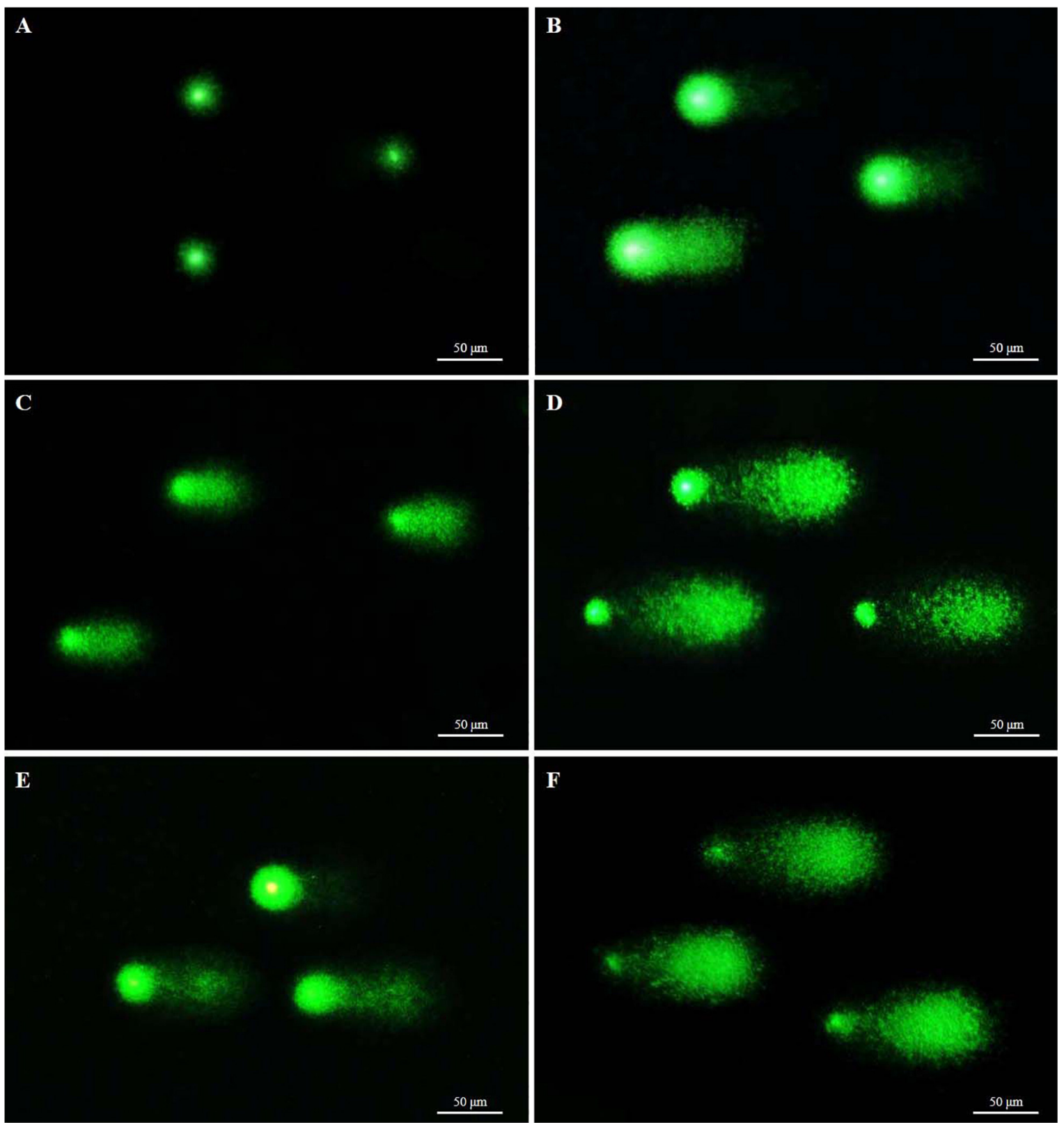

FIGURE 7 | Fluorescent images of fresh and cryopreserved sperm after comet assay. Each comet represents damaged or undamaged DNA in sperm. (A) Intact nuclei of fresh sperm; (B) slightly damaged nuclei of sperm cryopreserved with $8 \% \mathrm{Me}_{2} \mathrm{SO}$; (C) slightly damaged nuclei of sperm cryopreserved with $8 \%$ EG; (D) fragmented tail DNA of sperm cryopreserved with 6\% PG; (E) slightly damaged nuclei of sperm cryopreserved with $2 \%$ GLY; and (F) fragmented tail DNA of sperm cryopreserved with $2 \% \mathrm{MeOH}$. The comet gel was stained with Vista green dye. 
TABLE 6 | Correlation coefficient $(r)$ between sperm quality parameters of Pacific abalone, H. discus hannai.

\begin{tabular}{|c|c|c|c|c|c|}
\hline & Al (\%) & PMI (\%) & $\begin{array}{l}\text { MMP } \\
(\%)\end{array}$ & $\begin{array}{l}\text { DNA fragmentation } \\
\qquad(\%)\end{array}$ & $\begin{array}{c}\text { Fertilization } \\
(\%)\end{array}$ \\
\hline Motility (\%) & $0.990^{\star \star}$ & $0.988^{\star \star}$ & $0.992^{\star \star}$ & $-0.958^{\star \star}$ & $0.989^{\star \star}$ \\
\hline $\mathrm{Al}(\%)$ & & $0.996^{\star \star}$ & $0.995^{\star \star}$ & $-0.950^{\star \star}$ & $0.977^{\star \star}$ \\
\hline PMI (\%) & & & $0.991^{\star \star}$ & $-0.951^{\star \star}$ & $0.975^{\star \star}$ \\
\hline MMP (\%) & & & & $-0.931^{\star \star}$ & $0.978^{\star \star}$ \\
\hline $\begin{array}{l}\text { DNA } \\
\text { fragmentation } \\
(\%)\end{array}$ & & & & & $-0.983^{\star \star}$ \\
\hline
\end{tabular}

${ }^{* *}$ Correlation is significant at $P<0.01$.

for the industry. Considering the lack of information in the previous report, the present study assessed motility regulating gene expression levels, motility, morphology, AI, PMI, MMP, DNA integrity, fertilization rate, and hatching rate of post thaw sperm of $H$. discuss hannai.

The present study reported $\mathrm{Na}^{+}$and $\mathrm{Cl}^{-}$as predominant ions of Pacific abalone seminal plasma with high osmotic pressure. The consistent results were previously reported from seminal plasma of Pacific oyster (Boulais et al., 2018). The level of $\mathrm{Ca}^{2+}$ ion $(10.3 \pm 0.1 \mathrm{mM})$ in the present study was also similar to previously reported levels of $\mathrm{Ca}^{2+}$ ion for Pacific oyster (Boulais et al., 2018), but slightly higher than those values for Japanese scallop (Alavi et al., 2014). Those parameters (osmolarity, $\mathrm{pH}$, and ion compositions) of seminal plasma are considered as biomarkers of sperm quality (Rurangwa et al., 2004; Lanes et al., 2010).

Quantitative PCR-based quantification is a useful method to determine post thaw sperm quality (Guerra et al., 2013; Valcarce et al., 2013; Riesco et al., 2019). mRNA expression levels of HSPs (HSP70 and HSP90) based on qPCR have been recommended as molecular markers to predict the fertilization capacity of post thaw sperm (Riesco et al., 2019). To the best of our knowledge, for mollusks, this tool has been applied only for oyster sperm (Riesco et al., 2019). The present study determined mRNA levels of ion channel regulating genes (PKAC, HSP70, and HSP90) of cryopreserved sperm. Ion channel regulates the motility and fertility of sperm (Ren et al., 2001; Navarro et al., 2008). Results of the present study revealed that the expression of PKA-C is suppressed in post thaw sample than in fresh sperm. Cryopreserved sperm of Atlantic salmon also shows reduced PKA activity than fresh sperm (Lee-Estevez et al., 2019). Kong et al. (2020) have reported that PKA-C can regulate sperm motility of Pacific abalone. Considering the above facts, reduced motility of post thaw sperm might be responsible for the lower mRNA expression of PKA-C gene found in the present study. Sperm cryopreserved with $8 \% \mathrm{Me}_{2} \mathrm{SO}$ showed higher mRNA expression levels of PKA$\mathrm{C}$ than sperm cryopreserved with other cryoprotectants, but not significantly different from sperm cryopreserved with $8 \%$ EG. The present study is the first to report mRNA expression patterns of PKA-C in cryopreserved sperm. However, post thaw sperm samples showed significantly $(p<0.05)$ reduced mRNA expression levels of HSP70 and HSP90 genes than fresh sperm.
This finding is consistent with previously reported results of oyster (Riesco et al., 2019), yellow catfish (Bai et al., 2019), and bull (Zhang et al., 2015a,b) sperm. These results indicate that cryopreservation with penetrating CPAs $\left(\mathrm{Me}_{2} \mathrm{SO}, \mathrm{EG}, \mathrm{PG}\right.$, GLY, and $\mathrm{MeOH}$ ) can denature motility regulating gene of Pacific abalone sperm.

Effects of cryopreservation on motility, MMP, vitality, and fertilization of sperm of several fish and shellfish species have been reported previously (Maria et al., 2006; Viveiros et al., 2009, 2012; Liu et al., 2014). Motility is the most frequently used parameter to assess post thaw sperm quality. It is usually well interconnected with fertility (Costa et al., 2020). The present study found that post thawed sperm cryopreserved with $8 \% \mathrm{Me}_{2} \mathrm{SO}$ and $2 \% \mathrm{MeOH}$ were the most motile and immotile ones, respectively. CPAs exhibited significant $(p<0.05)$ effects on post thaw motility, supporting previous findings for Pacific abalone (Kim et al., 2020a). Motility reduction is the most observed alteration of cryopreserved sperm quality. Post thaw motility is a useful indicator to evaluate cryopreservation effect and predict sperm fertility (Yang et al., 2010).

Sperm consists of several parts bounded by the acrosomal membrane, plasma membrane, and mitochondrial membrane. Sperm competency depends on the intactness of these three membrane compartments (Paniagua-Chávez et al., 2006). This study assessed the intactness of these compartments of cryopreserved sperm using a fluorescent technique (Figure 5).

Acrosome integrity is a vital factor for successful fertilization, which can be detected using LYSO-G dye (Cunha et al., 2015). The present study reported improved AI from post thaw sperm suspended with $8 \%$ EG. This result predicts that EG is comparatively susceptible for AI than other CPAs. Our previous report shows improved AI than present findings when sperm were cryopreserved using $8 \% \mathrm{Me}_{2} \mathrm{SO}$ (Kim et al., 2020a).

Plasma membrane integrity is the most investigated physiological indicator of cryopreserved sperm (Figueroa et al., 2016). PMI is crucial for sperm quality (Maxwell and Salamon, 1993) because PMI plays a vital role in sperm oocyte fusion (Alcay et al., 2020). In the present study, sperm cryopreserved with $8 \%$ EG showed higher PMI values than sperm cryopreserved with other CPAs, although their PMI values were significantly $(p<0.05)$ lower than PMI values of fresh sperm. The present findings indicate that each CPA has specific effects on sperm during the cryopreservation process which might be responsible for variations of post thaw sperm PMI. Impaired PMI is responsible for inferior motility of post thaw sperm (Xin et al., 2020). This result is consistent with cryopreserved sperm of $H$. laevigata (Liu et al., 2014) and H. rufescens (Salinas-Flores et al., 2005). Our previous report shows improved PMI than present findings when sperm were cryopreserved using $8 \% \mathrm{Me}_{2} \mathrm{SO}$ (Kim et al., 2020a).

Mitochondrial membrane potential not only depicts the motility but also indicates the overall health status of sperm (Agnihotri et al., 2016). The present study revealed that sperm cryopreserved with $8 \% \mathrm{EG}$ and $2 \% \mathrm{MeOH}$ had the highest and lowest MMP values, respectively. These findings suggest 


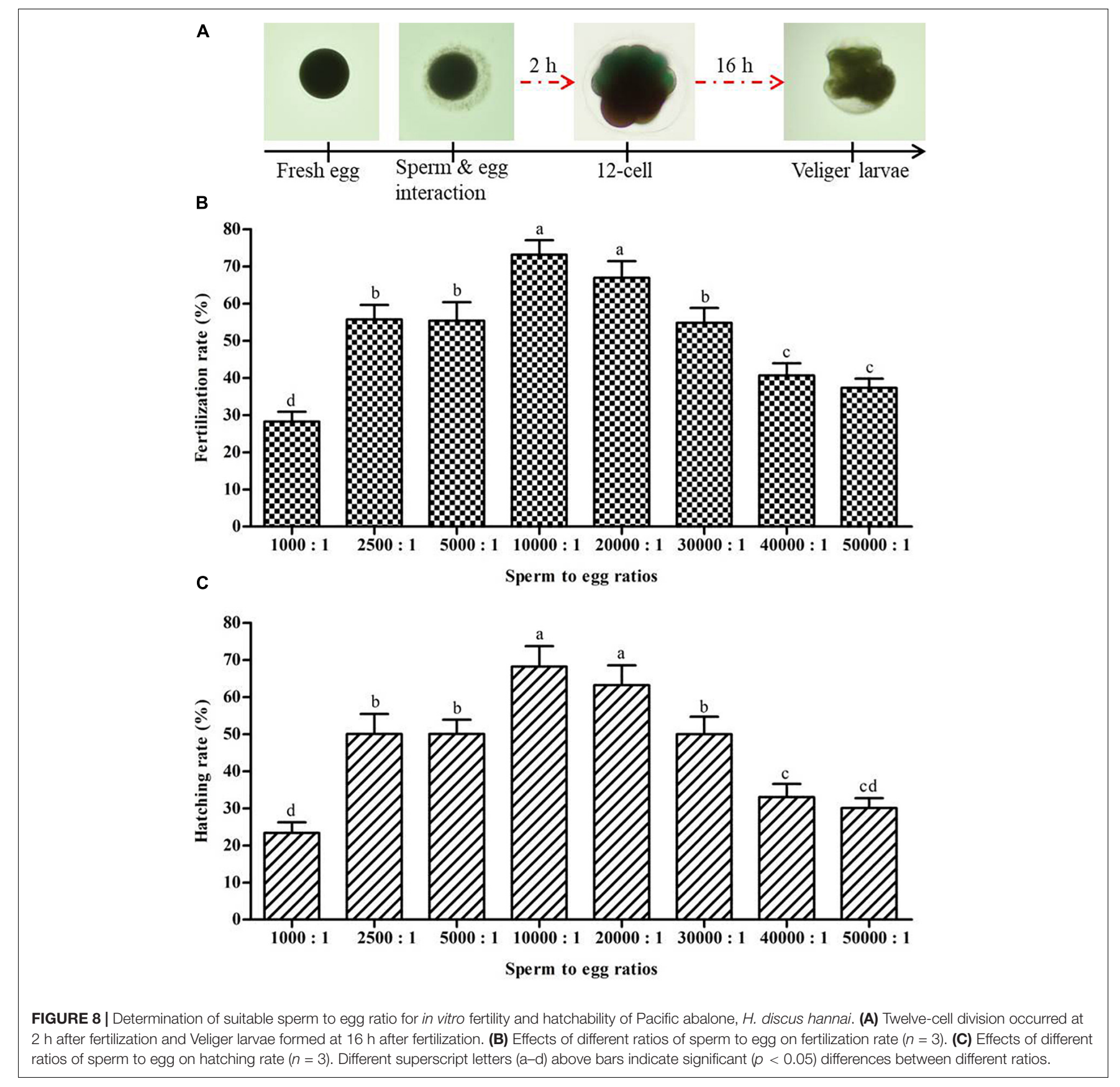

that $\mathrm{MeOH}$ can promote mitochondrial damage of post thaw sperm. The present study also revealed lower MMP values than PMI values for all types of cryopreserved sperm. A similar phenomenon has been previously described for cryopreserved sperm of $H$. iris (Adams et al., 2003) and $H$. laevigata (Liu et al., 2014).

It has been confirmed that the freezing process can cause injuries to both head and tail of sperm (Galo et al., 2019). CPAs' toxicity and temperature reduction are responsible for such sperm abnormalities. Morphological defects of tail and midpiece have been reported as factors that decrease the motility and fertility of sperm (Kavamoto et al., 2018). The present study found that neck folding is the most frequent abnormality of fresh sperm. However, for cryopreserved sperm, total structure damage had the highest frequency of abnormalities. Abnormalities including total structure damage, abnormal body shape, coiled tail, and droplet in tail were only observed for cryopreserved sperm. Morphological abnormalities were previously reported from cryopreserved sperm of zebrafish and seven-band grouper (Costa et al., 2020; Kim et al., 2020b). Cryo-injury of post thaw sperm can occur due to several causative factors such as cold shock, ice crystallization, CPA toxicity, $\mathrm{pH}$ fluctuation, and osmotic effect (Chao and Liao, 2001; Chatiza et al., 2011; 


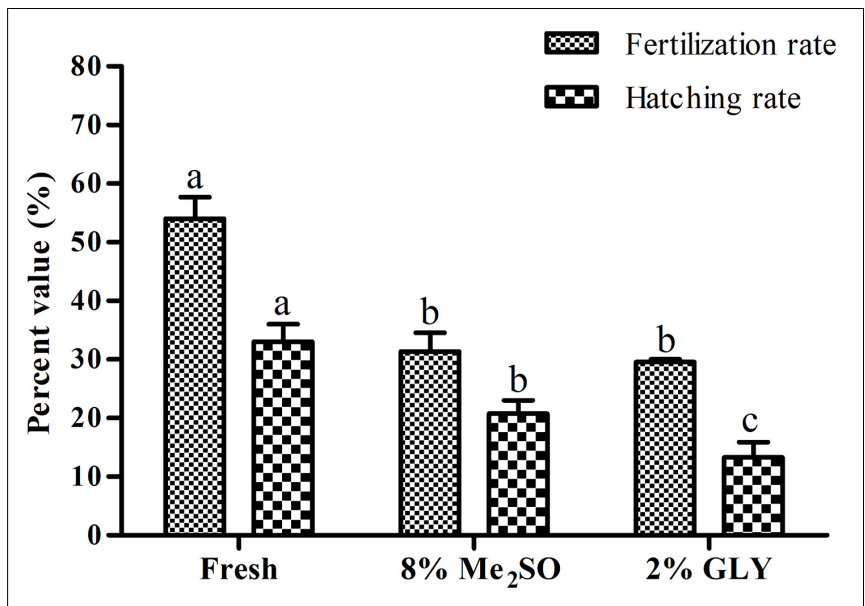

FIGURE 9 | Fertilization and hatching rates of cryopreserved sperm of Pacific abalone $(n=3)$. Different superscript letters ( $\mathrm{a}$ and $\mathrm{b})$ above bars indicate significant $(p<0.05)$ differences between different treatments. of cryopreserved sperm of red abalone, H. rufescens (SalinasFlores et al., 2005), but lower than that of cryopreserved sperm of H. laevigata reported by Liu et al. (2014).

\section{CONCLUSION}

The present study used molecular markers based on qPCR-based quantification to determine post thaw sperm quality of Pacific abalone. The present findings revealed that cryopreservation suppressed the expression of PKA-C, HSP70, and HSP90 gene in sperm of Pacific abalone. Sperm cryopreserved with $8 \%$ $\mathrm{Me}_{2} \mathrm{SO}$ showed relatively less molecular changes of genes, DNA fragmentation, and morphological deformities than those cryopreserved with other CPAs. Both molecular and florescent techniques proved that $\mathrm{Me}_{2} \mathrm{SO}$ was comparatively suitable as a cryoprotectant for sperm cryopreservation of Pacific abalone as well as for fertilization practice in the hatchery.

\section{DATA AVAILABILITY STATEMENT}

Balamurugan et al., 2019). The present study confirmed their evidence by reporting the remarkable abnormalities after freeze-thaw process.

The present study revealed interrelationships among sperm quality indicators of $H$. discus hannai. Sperm motility showed positive relationships with all parameters except DNA fragmentation, consistent with results of eastern oyster, Crassostrea virginica (Paniagua-Chávez et al., 2006). However, DNA fragmentation exhibited strongly negative relationships $(p<0.01)$ with all indicators of sperm quality, consistent with the findings of Alcay et al. (2020). These results suggest that reduction of motility, $\mathrm{AI}, \mathrm{PMI}$, and $\mathrm{MMP}$ might be related to sperm DNA fragmentation.

Fertility is an important parameter to evaluate post thaw sperm quality. Sperm to egg ratio and sperm quality are key factors affecting fertilization and hatching success in an artificial breeding program (Trippel and Neilson, 1992; Linhart et al., 2008; Gallego et al., 2013). High sperm concentrations may damage the jelly layer and membranes of eggs and lead to unfertilized or abnormal embryos (Gwo et al., 2002). In the present study, the highest fertilization rate was obtained with a sperm to egg ratio of 10,000:1. A similar ratio of sperm to egg that leads to high fertilization rate has been reported for H. laevigata (Liu et al., 2014) and Crassostrea gigas (Gwo et al., 2003; Adams et al., 2008). Thus, sperm to egg ratio of 10,000:1 was maintained in the fertilization experiment of cryopreserved sperm. The present study revealed that fertilization and hatching rates of cryopreserved sperm were significantly $(p<0.05)$ lower than those of fresh sperm. The fertilization rate of sperm cryopreserved with $8 \% \mathrm{Me}_{2} \mathrm{SO}$ was not significantly $(p>0.05)$ different from that of sperm cryopreserved with $2 \%$ GLY, although the hatching rate of sperm cryopreserved with $8 \% \mathrm{Me}_{2} \mathrm{SO}$ was significantly different from that of sperm cryopreserved with $2 \%$ GLY. The present study also revealed that the fertilization rate of post thaw sperm was higher than that
The original contributions presented in the study are included in the article/supplementary materials, further inquiries can be directed to the corresponding author/s.

\section{ETHICS STATEMENT}

Experimental protocols were approved by the Animal Care and Use Committee of Chonnam National University (CNU IACUCYS-2020-5).

\section{AUTHOR CONTRIBUTIONS}

KK conceptualized the study. SH, ZS, and KK performed the methodology. SH performed data curation, visualization, and investigation. KK did supervision, validation, and fund acquisition. $\mathrm{SH}$ and $\mathrm{KK}$ wrote the original paper. $\mathrm{SH}, \mathrm{ZS}$, and $\mathrm{KK}$ performed review and editing. All authors read and agreed to the published version of the manuscript.

\section{FUNDING}

This research was part of the project entitled "Development of technology for abalone aquaculture using sperm cryopreservation (Grant No. 2018-2129)" funded by the Ministry of Oceans and Fisheries, South Korea.

\section{ACKNOWLEDGMENTS}

The authors are grateful to the central laboratory of Yeosu campus, CNU for instrumental support in ion composition analysis. and software analysis. SH, ZS, and YC did formal analysis 


\section{REFERENCES}

Adams, S. L., Hessian, P. A., and Mladenov, P. V. (2003). Flow cytometric evaluation of mitochondrial function and membrane integrity of marine invertebrate sperm. Inverteb. Reproduct. Dev. 44, 45-51. doi: 10.1080/07924259. 2003.9652552

Adams, S. L., Smith, J. F., Roberts, R. D., Janke, A. R., King, N. G., Tervit, H. R., et al. (2008). Application of sperm cryopreservation in selective breeding of the Pacific oyster, Crassostrea gigas (Thunberg). Aquac. Res. 39, 1434-1442. doi: 10.1111/j.1365-2109.2008.02013.x

Agnihotri, S. K., Agrawal, A. K., Hakim, B. A., Vishwakarma, A. L., Narender, T., Sachan, R., et al. (2016). Mitochondrial membrane potential (MMP) regulates sperm motility. In Vitro Cell. Dev. Biol. Anim. 52, 953-960. doi: 10.1007/s11626016-0061-x

Alavi, S. M. H., Matsumura, N., Shiba, K., Itoh, N., Takahashi, K. G., Inaba, K., et al. (2014). Roles of extracellular ions and $\mathrm{pH}$ in 5-HT-induced sperm motility in marine bivalve. Reproduction 147, 331-345.

Alcay, S., Ustuner, B., Aktar, A., Mulkpinar, E., Duman, M., Akkasoglu, M., et al. (2020). Goat semen cryopreservation with rainbow trout seminal plasma supplemented lecithin-based extenders. Andrologia 52:e13555.

Alshawa, E., Laqqan, M., Montenarh, M., and Hammadeh, M. E. (2019). Influence of cryopreservation on the CATSPER2 and TEKT2 expression levels and protein levels in human spermatozoa. Toxicol. Rep. 6, 819-824. doi: 10.1016/ j.toxrep.2019.08.004

Bai, C., Kang, N., Zhao, J., Dai, J., Gao, H., Chen, Y., et al. (2019). Cryopreservation disrupts lipid rafts and heat shock proteins in yellow catfish sperm. Cryobiology 87, 32-39. doi: 10.1016/j.cryobiol.2019.03.004

Balamurugan, R., Prapaporn, W., and Munuswamy, N. (2019). Sperm activation and effects of cryopreservation on motility, ultrastructure and DNA integrity in Grey mullet Mugil cephalus. Aquac. Rep. 14:100204. doi: 10.1016/j.aqrep.2019. 100204

Boulais, M., Suquet, M., Arsenault-Pernet, E. J., Malo, F., Queau, I., Pignet, P., et al. (2018). pH controls spermatozoa motility in the Pacific oyster (Crassostrea gigas). Biol. Open 7:bio031427. doi: 10.1242/bio.031427

Chao, N. H., and Liao, I. C. (2001). Cryopreservation of finfish and shellfish gametes and embryos. Aquaculture 197, 161-189. doi: 10.1016/S0044-8486(01) 00586- 5

Chatiza, F. P., Pieterse, G. M., Bartels, P., and Nedambale, T. L. (2011). Characterization of epididymal spermatozoa motility rate, morphology and longevity of springbok (Antidorcas marsupialis), impala (Aepyceros melampus) and blesbok (Damaliscus dorcus phillipsi): pre-and post-cryopreservation in South Africa. Anim. Reprod. Sci. 126, 234-244. doi: 10.1016/j.anireprosci.2011. 04.022

Cheng, P., Liu, X., Zhang, G., and He, J. (2007). Cloning and expression analysis of a HSP70 gene from Pacific abalone (Haliotis discus hannai). Fish Shellfish Immunol. 22, 77-87. doi: 10.1016/j.fsi.2006.03.014

Costa, B. B. D., Oliveira, D. L. D., Rodrigues, R. B., Gomes, I. C., and Streit, D. P. Jr. (2020). Morphological abnormalities in zebrafish cryopreserved sperm. Cryobiology 97, 235-237. doi: 10.1016/j.cryobiol.2020.08.003

Cunha, A. T. M., Carvalho, J. D. O., and Dode, M. A. N. (2015). Techniques for sperm evaluation using fluorescent probes. Semin. Ciênc. Agrár. 36, 4365-4376. doi: 10.5433/1679-0359.2015v36n6Supl2p4365

Figueroa, E., Merino, O., Risopatrón, J., Isachenko, V., Sánchez, R., Effer, B., et al. (2015). Effect of seminal plasma on Atlantic salmon (Salmo salar) sperm vitrification. Theriogenology 83, 238-245. doi: 10.1016/j.theriogenology.2014. 09.015

Figueroa, E., Valdebenito, I., and Farias, J. G. (2016). Technologies used in the study of sperm function in cryopreserved fish spermatozoa. Aquac. Res. 47, 1691-1705. doi: 10.1111/are.12630

Gallego, V., Pérez, L., Asturiano, J. F., and Yoshida, M. (2013). Relationship between spermatozoa motility parameters, sperm/egg ratio, and fertilization and hatching rates in pufferfish (Takifugu niphobles). Aquaculture 416, 238-243. doi: 10.1016/j.aquaculture.2013.08.035

Galo, J. M., Streit-Junior, D. P., Oliveira, C. A., Povh, J. P., Fornari, D. C., Digmayer, M., et al. (2019). Quality of fresh and cryopreserved semen and their influence on the rates of fertilization, hatching and quality of the larvae of Piaractus mesopotamicus. Braz. J. Biol. 79, 438-445. doi: 10.1590/1519-6984.182391
Guerra, S. M., Valcarce, D. G., Cabrita, E., and Robles, V. (2013). Analysis of transcripts in gilthead seabream sperm and zebrafish testicular cells: mRNA profile as a predictor of gamete quality. Aquaculture 406, 28-33. doi: 10.1016/j. aquaculture.2013.04.032

Gwo, J. C., Chen, C. W., and Cheng, H. Y. (2002). Semen cryopreservation of small abalone (Haliotis diversicolor supertexa). Theriogenology 58, 1563-1578. doi: $10.1016 / \mathrm{s} 0093-691 \times(02) 01055-5$

Gwo, J. C., Wu, C. Y., Chang, W. S. P., and Cheng, H. Y. (2003). Evaluation of damage in Pacific oyster (Crassostrea gigas) spermatozoa before and after cryopreservation using comet assay. Cryoletters $24,171-180$.

Hezavehei, M., Sharafi, M., Kouchesfahani, H. M., Henkel, R., Agarwal, A. Esmaeili, V., et al. (2018). Sperm cryopreservation: a review on current molecular cryobiology and advanced approaches. Reprod. Biomed. Online 37, 327-339. doi: 10.1016/j.rbmo.2018.05.012

Kavamoto, E. T., Barnabe, V. H., Santo de Campos, B. D. E., and de AndradeTalmelli, E. F. (2018). Abnormal morphology of "curimbatá" Prochilodus scrofa (Steindachner,1881) (Osteichthyes, Characiformes, Prochilodontidae) spermatozoa. Bol. Inst. Pesca 25, 61-66.

Kim, S. C., Hossen, S., and Kho, K. H. (2020a). Cryopreservation of sperm from farmed Pacific abalone, Haliotis discus hannai. Cryobiology 94, 49-56. doi: 10. 1016/j.cryobiol.2020.04.011

Kim, S. C., Hossen, S., and Kho, K. H. (2020b). Effects of 3 years of cryopreservation on sperm quality of seven-band grouper, Epinephelus septemfasciatus. Aquac Res. 51, 3050-305351. doi: 10.1111/are.14615

Kong, N., Li, H., Yang, W., Fu, Q., Gong, C., Wang, L., et al. (2020). The effects of protein kinase a catalytic subunit on sperm motility regulation in Pacific abalone Haliotis discus hannai. Aquac. Res. 51, 2525-2534. doi: 10.1111/are. 14595

Lanes, C. F. C., Okamoto, M. H., Bianchini, A., Marins, L. F., and Sampaio, L. A. (2010). Sperm quality of Brazilian flounder Paralichthys orbignyanus throughout the reproductive season. Aquac. Res. 41, e199-e207. doi: 10.1111/ j.1365-2109.2010.02501.x

Lee-Estevez, M., Herrera, L., Díaz, R., Beltrán, J., Figueroa, E., Dumorné, K., et al. (2019). Effects of cryopreservation on cAMP-dependent protein kinase and AMP-activated protein kinase in Atlantic salmon (Salmo salar) spermatozoa: Relation with post-thaw motility. Anim. Reprod. Sci. 209:106133. doi: 10.1016/ j.anireprosci.2019.106133

Li, K., Sun, P., Wang, Y., Gao, T., Zheng, D., Liu, A., et al. (2020). Hsp90 interacts with Cdc37, is phosphorylated by PKA/PKC, and regulates Src phosphorylation in human sperm capacitation. Andrology 2, 1-11. doi: 10.1111/andr.12862

Li, K., Xue, Y., Chen, A., Jiang, Y., Xie, H., Shi, Q., et al. (2014). Heat shock protein 90 has roles in intracellular calcium homeostasis, protein tyrosine phosphorylation regulation, and progesterone-responsive sperm function in human sperm. PLoS One 9:e115841. doi: 10.1371/journal.pone.0115841

Lindemann, C. B., and Kanous, K. S. (1989). Regulation of mammalian sperm motility. Arch. Androl. 23, 1-22. doi: 10.3109/01485018908986783

Linhart, O., Alavi, S. M. H., Rodina, M., Gela, D., and Cosson, J. (2008) Comparison of sperm velocity, motility and fertilizing ability between firstly and secondly activated spermatozoa of common carp (Cyprinus carpio). J. Appl. Ichthyol. 24, 386-392. doi: 10.1111/j.1439-0426.2008.01138.x

Liu, Y., Xu, T., Robinson, N., Qin, J., and Li, X. (2014). Cryopreservation of sperm in farmed Australian greenlip abalone Haliotis laevigata. Cryobiology 68, 185-193. doi: 10.1016/j.cryobiol.2014.01.002

Livak, K. J., and Schmittgen, T. D. (2001). Analysis of relative gene expression

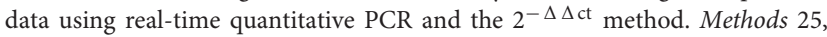
402-408. doi: 10.1006/meth.2001.1262

Ma, H., Xu, W., Mai, K., Liufu, Z., and Chen, H. (2004). Cloning and characterization of an abalone (Haliotis discus hannai) actin gene. J Ocean Univ. China 3, 145-149. doi: 10.1007/s11802-004-0025-8

Madeddu, M., Berlinguer, F., Pasciu, V., Succu, S., Satta, V., Leoni, G. G., et al. (2010). Differences in semen freezability and intracellular ATP content between the rooster (Gallus gallus domesticus) and the Barbary partridge (Alectoris barbara). Theriogenology 74, 1010-1018. doi: 10.1016/j.theriogenology.2010.05. 001

Mannowetz, N., Miller, M. R., and Lishko, P. V. (2017). Regulation of the sperm calcium channel CatSper by endogenous steroids and plant triterpenoids. Proc. Natl. Acad. Sci. U.S.A. 114, 5743-5748. doi: 10.1073/pnas.1700367114 
Maria, A. N., Viveiros, A. T. M., Orfão, L. H., Oliveira, A. V., and Moraes, G. F. (2006). Effects of cooling and freezing on sperm motility of the endangered fish piracanjuba Brycon orbignyanus (Characiformes. Characidae). Anim. Reprod. 3 , 55-60.

Maxwell, W. M., and Salamon, S. (1993). Liquid storage of ram semen: a review. Reprod. Fertil. Dev. 5, 613-638. doi: 10.1071/rd9930613

Navarro, B., Kirichok, Y., Chung, J. J., and Clapham, D. E. (2008). Ion channels that control fertility in mammalian spermatozoa. Int. J. Dev. Biol. 52:607.

Nomura, M., Beltran, C., Darszon, A., and Vacquier, V. D. (2005). A soluble adenylyl cyclase from sea urchin spermatozoa. Gene 353, 231-238. doi: 10.1016/ j.gene.2005.04.034

O'connell, M., McClure, N., and Lewis, S. E. M. (2002). The effects of cryopreservation on sperm morphology, motility and mitochondrial function. Hum. Reprod 17, 704-709. doi: 10.1093/humrep/17.3.704

Orta, G., De La Vega-Beltran, J. L., Martín-Hidalgo, D., Santi, C. M., Visconti, P. E., and Darszon, A. (2018). CatSper channels are regulated by protein kinase A. J. Biol. Chem. 293, 16830-16841. doi: 10.1074/jbc.RA117.001566

Paniagua-Chávez, C. G., Jenkins, J., Segovia, M., and Tiersch, T. R. (2006). Assessment of gamete quality for the eastern oyster (Crassostrea virginica) by use of fluorescent dyes. Cryobiology 53, 128-138. doi: 10.1016/j.cryobiol.2006. 05.001

Pereira, G. R., Becker, E. G., Siqueira, L. C., Ferreira, R., Severo, C. K., Truzzi, V. S., et al. (2010). Assessment of bovine spermatozoa viability using different cooling protocols prior to cryopreservation. Ital. J. Anim. Sci. 9, 465-470. doi: 10.4081/ijas.2010.e88

Peris-Frau, P., Soler, A. J., Iniesta-Cuerda, M., Martín-Maestro, A., SánchezAjofrín, I., Medina-Chávez, D. A., et al. (2020). Sperm cryodamage in ruminants: understanding the molecular changes induced by the cryopreservation process to optimize sperm quality. Int. J. Mol. Sci. 21:2731. doi: $10.3390 /$ ijms 21082781

Ren, D., Navarro, B., Perez, G., Jackson, A. C., Hsu, S., Shi, Q., et al. (2001). A sperm ion channel required for sperm motility and male fertility. Nature 413, 603-609. doi: 10.1038/35098027

Riesco, M. F., Félix, F., Matias, D., Joaquim, S., Suquet, M., and Cabrita, E. (2019). Comparative study on cellular and molecular responses in oyster sperm revealed different susceptibilities to cryopreservation. Aquaculture 498, 223-229. doi: 10.1016/j.aquaculture.2018.08.049

Rurangwa, E., Kime, D. E., Ollevier, F., and Nash, J. P. (2004). The measurement of sperm motility and factors affecting sperm quality in cultured fish. Aquaculture 234, 1-28. doi: 10.1016/j.aquaculture.2003.12.006

Salinas-Flores, L., Paniagua-Chavez, C. G., Jenkins, J. A., and Tiersch, T. R. (2005). Cryopreservation of sperm of red abalone (Haliotis rufescens). J. Shellfish Res. 24, 415-420.

Sharker, M. R., Hossen, S., Nou, I. S., and Kho, K. H. (2020a). Characterization of insulin-like growth factor binding protein 7 (igfbp7) and its potential involvement in shell formation and metamorphosis of Pacific abalone, Haliotis discus hannai. Int. J. Mol. Sci. 21:6529. doi: 10.3390/ijms21186529

Sharker, M. R., Kim, S. C., Hossen, S., and Kho, K. H. (2020b). Characterization of insulin-like growth factor binding Protein-5 (IGFBP-5) gene and its potential roles in ontogenesis in the Pacific Abalone, Haliotis discus hannai. Biology 9:216. doi: 10.3390/biology9080216

Sukhan, Z. P., Sharker, M. R., and Kho, K. H. (2020). Molecular cloning, in silico characterization and expression analysis of axonemal protein 66.0 in Pacific abalone, Haliotis discus hannai. Eur. Zool. J. 87, 648-658. doi: 10.1080/ 24750263.2020.1821800

Suleria, H. A. R., Masci, P. P., Gobe, G. C., and Osborne, S. A. (2017). Therapeutic potential of abalone and status of bioactive molecules: a comprehensive review. Crit. Rev. Food Sci. Nutr. 57, 1742-1748. doi: 10.1080/10408398.2015.1031726
Trippel, E. A., and Neilson, J. D. (1992). Fertility and sperm quality of virgin and repeat-spawning Atlantic cod (Gadus morhua) and associated hatching success. Can. J. Fish. Aquat. Sci. 49, 2118-2127. doi: 10.1139/f92-235

Vacquier, V. D., Loza-Huerta, A., García-Rincón, J., Darszon, A., and Beltrán, C. (2014). Soluble adenylyl cyclase of sea urchin spermatozoa. Biochim. Biophys. Acta 1842, 2621-2628. doi: 10.1016/j.bbadis.2014.07.011

Valcarce, D. G., Cartón-García, F., Herráez, M. P., and Robles, V. (2013). Effect of cryopreservation on human sperm messenger RNAs crucial for fertilization and early embryo development. Cryobiology 67, 84-90. doi: 10.1016/j.cryobiol.2013. 05.007

Viveiros, A. T. M., Isaú, Z. A., Caneppele, D., and Leal, M. C. (2012). Sperm cryopreservation affects postthaw motility, but not embryogenesis or larval growth in the Brazilian fish Brycon insignis (Characiformes). Theriogenology 78, 803-810. doi: 10.1016/j.theriogenology.2012.03.028

Viveiros, A. T. M., Orfão, L. H., Maria, A. N., and Allaman, I. B. (2009). A simple, inexpensive and successful freezing method for curimba Prochilodus lineatus (Characiformes) semen. Anim. Reprod. Sci. 112, 293-300. doi: 10.1016/ j.anireprosci.2008.04.025

Wooley, D. M., and Richardson, D. W. (1978). Ultrastructural injury to human spermatozoa after freezing and thawing. J. Reprod. Fert. 53, 389-394. doi: 10. 1530/jrf.0.0530389

Xin, M., Niksirat, H., Shaliutina-Kolešová, A., Siddique, M. A. M., Sterba, J., Boryshpolets, S., et al. (2020). Molecular and subcellular cryoinjury of fish spermatozoa and approaches to improve cryopreservation. Rev. Aquac. 12, 909-924. doi: 10.1111/raq.12355

Yang, H., Norris, M., Winn, R., and Tiersch, T. R. (2010). Evaluation of cryoprotectant and cooling rate for sperm cryopreservation in the euryhaline fish medaka Oryzias latipes. Cryobiology 61, 211-219. doi: 10.1016/j.cryobiol. 2010.07.006

Zhang, W., Wu, C., Mai, K., Chen, Q., and Xu, W. (2011). Molecular cloning, characterization and expression analysis of heat shock protein 90 from Pacific abalone, Haliotis discus hannai Ino in response to dietary selenium. Fish Shellfish Immunol. 30, 280-286. doi: 10.1016/j.fsi.2010.10.019

Zhang, X. G., Hong, J. Y., Yan, G. J., Wang, Y. F., Li, Q. W., and Hu, J. H. (2015a). Association of heat shock protein 70 with motility of frozen-thawed sperm in bulls. Czech J. Anim. Sci. 60, 256-262. doi: 10.17221/8239-CJAS

Zhang, X. G., Hu, S., Han, C., Zhu, Q. C., Yan, G. J., and Hu, J. H. (2015b). Association of heat shock protein 90 with motility of post-thawed sperm in bulls. Cryobiology 70, 164-169. doi: 10.1016/j.cryobiol.2014.12.010

Zilli, L., Schiavone, R., and Vilella, S. (2017). Role of protein phosphorylation/dephosphorylation in fish sperm motility activation: State of the art and perspectives. Aquaculture 472, 73-80. doi: 10.1016/j.aquaculture.2016.03.043

Zilli, L., Schiavone, R., Zonno, V., Storelli, C., and Vilella, S. (2003). Evaluation of DNA damage in Dicentrarchus labrax sperm following cryopreservation. Cryobiology 47, 227-235. doi: 10.1016/j.cryobiol.2003. 10.002

Conflict of Interest: The authors declare that the research was conducted in the absence of any commercial or financial relationships that could be construed as a potential conflict of interest.

Copyright (c) 2021 Hossen, Sukhan, Cho and Kho. This is an open-access article distributed under the terms of the Creative Commons Attribution License (CC BY). The use, distribution or reproduction in other forums is permitted, provided the original author(s) and the copyright owner(s) are credited and that the original publication in this journal is cited, in accordance with accepted academic practice. No use, distribution or reproduction is permitted which does not comply with these terms. 